Pamiętnik Literacki 2021, 3, s. 179-209

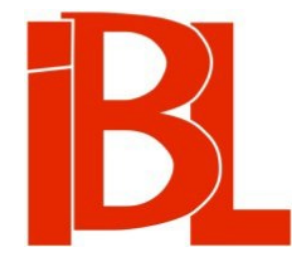

\title{
Problem ustalenia podstawy krytycznego wydania „Vade-mecum”
}

Piotr Chlebowski 


\section{2. $\begin{array}{llllllllllllllllll} & \mathrm{M} & \mathrm{A} & \mathrm{T} & \mathrm{E} & \mathrm{R} & \mathrm{I} & \mathrm{A} & \mathrm{E} & \mathrm{Y} & \mathrm{I} & \mathrm{N} & \mathrm{O} & \mathrm{T} & \mathrm{A} & \mathrm{T} & \mathrm{K} & \mathrm{I}\end{array}$}

Pamiętnik Literacki CXII, 2021, z. 3, PL ISSN 0031-0514

DOI: $10.18318 / \mathrm{pl} .2021 .3 .10$

PIOTR CHLEBOWSKI Katolicki Uniwersytet Lubelski Jana Pawła II

\section{PROBLEM USTALENIA PODSTAWY KRYTYCZNEGO WYDANIA „VADE-MECUM"}

Artykuł będzie miał - tak przynajmniej bym pragną - charakter sumujący i porządkujący zjawiska i zagadnienia edytorskie, związane ze zbiorem poetyckim Cypriana Norwida. W niewielkim stopniu rości sobie pretensje do rewelatorstwa badawczego. Trudno tego oczekiwać od tak dobrze rozpoznanej problematyki. Vade-mecum bez wątpienia zdażyło już obrosnąć legendą tekstologiczną, choćby dotycząca jego pełnej edycji, która nie tylko się ciagnęła latami wówczas, gdy Norwid żył, ale także zaciążyła - dość dziwnym trafem - na edytorskiej biografii Zenona Przesmyckiego. Odkrył on przecież Norwida, niejako odzyskał jego twórczość dla polskiej kultury. Wielce zasłużył się jako wydawca dzieł pisarza, lecz zarazem nie zdołał (nie zdąży) opublikować w formie pełnej, integralnej zbioru poetyckiego ${ }^{1}$. Zostawił wprawdzie edycję niemal gotową do druku w swoim bezcennym archiwum ${ }^{2}$, ale to przedsięwzięcie przerwał wybuch drugiej wojny światowej.

Vade-mecum poznaliśmy zatem stosunkowo późno, a przy tym w sposób dość niecodzienny. Oto bowiem Wacław Borowy opracował (w 1947 r.) edycję faksymilowa jego autografu ${ }^{3}$. Natomiast pierwsza zwykła publikacja ukazała się dopiero

$1 \quad$ Ponad 40 wierszy z Vade-mecum Z. Przesmycki ogłosił w pierwszym tomie Ineditów (zob. C. N o rwi d, Reszta wierszy odszukanych po dziś, a dotad niewydrukowanych. Zebrał i wydał Z. Przes m y cki 〈Mir i a m〉. Warszawa 1933). Zbiór zawiera 69 wierszy. Pierwszą partię tekstów z Vade-mecum edytor opublikował w przełomowym t. 8 „Chimery” z 1904 r. (recte: 1905): znalazło się tu 16 wierszy. Natomiast 12 wierszy z Vade-mecum Przesmycki zamieścił w tomie: C. N or wi d, Poezje wybrane. Z całej odszukanej po dziś puścizny poety. Ułożył i przypisami opatrzył M i r i a m. Warszawa 1933 (recte: 1932). Szczątkowo publikowane przez Miriama przed drugą wojną światową teksty wierszy z Vade-mecum przedrukował T. Pini (C. N o rw i d, Dzieła. Wydał, objaśnił i wstępem krytycznym poprzedził T. Pin i. Warszawa 1934). Elementy zbioru rozparcelował jednak w ten sposób, że zupełnie je rozproszył, zrezygnował z odnotowywania, skąd pochodzą, nie przedrukował przedmowy autorskiej i pominął numery przynależne każdemu utworowi.

2 Z. Pr zes m y c k i, [Materiały z pracowni Norwidowskiej]. Cz. 1: Vade-mecum. Materiaty do wydania drukiem. Bibl. Narodowa, sygn. BN II 6323.

3 C. Norwid, Vade-mecum. Podobizna autografu. Przedm. W. B o r o w y. Warszawa 1947. Dalej do pozycji tej odsyłam skrótem VB. Ponadto stosuję następujące skróty do edycji dzieł C. N o r w i d a: DZ = Dzieła zebrane. Oprac. J. W. Gomuli cki. T. 1 (Wiersze. Tekst); t. 2 (Wiersze. Dodatek krytyczny). Warszawa 1966; PW = Pisma wszystkie. Zebrał, tekst ustalił, wstępem i uwagami krytycznymi opatrzył J. W. Go mulicki. T. 1-10. Warszawa 1971; VA = autograf Vade-mecum. Bibl. Narodowa, rkps BN II 6313; VL = Vade-mecum. Oprac. J. F e r t. Lublin 2004. W przypadku 
w 1953 r. za sprawą Kazimierza Sowińskiego poza granicami Polski, gdyż wydała ją londyńska Oficyna Poetów i Malarzy na Emigracji ${ }^{4}$. Później była edycja przygotowana przez Juliusza Wiktora Gomulickiego w 1962 r. ${ }^{5}$ i kolejne - poprawiane i uzupełniane edycje, w opracowaniu tegoż wydawcy: z r. 1966 włączona do 2-tomowych Dziet zebranych oraz do Pism wszystkich poety, a także edycja osobna z 1984 roku $^{6}$. Wreszcie po 1989 r. doczekaliśmy się całkowicie nowych publikacji Vade-mecum przygotowanych przez Józefa Ferta. Początkowo popularno-naukowych, wydanych w serii „Biblioteki Narodowej”" oraz „Skarby Biblioteki Narodowej” (pod auspicjami Ossolineum) ${ }^{8}$. Zwieńczeniem - jak dotychczas - tych starań jest pierwsze krytyczne wydanie zbioru opublikowane przez Ferta w 2004 r. jako osobny druk. Upraszczając, można wyodrębnić - i w sensie historycznym, i w sensie personalnym - dwa sposoby podejścia edytorskiego do Vade-mecum. To pierwsze reprezentuje Gomulicki, to drugie - Fert. Nie rozwijam tu kwestii krytyczności, choć i ona jest bardzo ważna, przede wszystkim odróżnia obu wydawców od siebie. Otóż Gomulicki, wbrew wyrażanym deklaracjom, nigdy nie przygotował wydania krytycznego, podczas gdy Fert wydanie takie zrealizował, co więcej, wykonał - zwłaszcza w partiach odmian - z akrybią, która w wielu przypadkach może nawet utrudnia filologiczno-edytorska lekturę tekstu. Celowo w tych omówieniach pomijam edycję Sowińskiego. Londyński wydawca, ograniczony sytuacją polityczną, mógł korzystać jedynie ze wspomnianej podobizny autografu Borowego, a nie z rękopisu znajdującego się w Bibliotece Narodowej, stąd liczne błędy, brak konsekwencji w traktowaniu tekstu i zawartych w nim autorskich poprawek, etc. ${ }^{9}$

Dzieło przechodziło różne koleje losu - i to za życia Norwida. Poeta przygotował czystopiśmienna, staranną redakcję zbioru, gdy dostał propozycje jego publikacji od Friedricha Arnolda Brockhausa (1865-1866) ${ }^{10}$. Ale tekst się nie ukazał. Wydawca wycofał się ze swojej propozycji. Dlaczego? Trudno ustalić przy braku dokumentacji. W literaturze przedmiotu najczęściej czytamy o niepewnej sytuacji politycznej,

Dzieł zebranych i Pism wszystkich liczby po łączniku oznaczają numery tomów, pozostałe - stronic. Jeśli chodzi o autograf Vade-mecum, po skrócie podaję numer karty.

C. K. Norwid, Vade-mecum. Oprac. K. Sowiński. Tunbridge Wells 1953.

5 C. Norwid, Vade-mecum. Wydał z autografu, uzupełnił i wstępem poprzedził J. W. G o m u licki. Warszawa 1962 (wyd. 2, zmien.: 1969).

6 C. Norwid, Vade-mecum. Tekst ustalił i wstępem krytycznym opatrzył J. W. Gomulicki. Lublin 1984.

7 C. Norwid, Vade-mecum. Oprac. J. Fert. Wrocław 1990. BN I 271 (wyd. 2, zmien.: 1999).

8 C. Norwid, Vade-mecum. Oprac. J. Fert. Wyd. 2, popr. i uzup. Wrocław 2003.

9 Tom przygotowany przez Sowińskiego nie zawiera żadnych objaśnień ani uwag, dlatego też trudno rozpoznać motywacje określonych decyzji edytorskich. Być może, miały się one znaleźć w sporządzonym, lecz nigdy nie zrealizowanym wydawniczo drugim tomie? Świadczy o tym informacja zamieszczona w tzw. stopce redakcyjnej (na końcu publikacji): „W przygotowaniu: drugi tom pt. Uzupetnienie do "Vade-mecum" (N or w i d, Vade-mecum 〈1953〉, s. 142).

10 O zamówieniu, jakie nadeszło $\mathrm{z}$ wydawnictwa F. A. Brockhaus, C. Norwid pisał w liście do J. Kuczyńskiej w połowie lipca 1865 (w: Dzieła wszystkie. T. 12: Listy. 3: 1862-1866. Oprac. J. Rudnicka. Uzup. E. Lijewska. Lublin-Warszawa 2019, s. 378). Trudno ustalić, kiedy poeta ukończył projektowany tom. Można zakładać, że wiosną 1866, gdyż w liście datowanym na 5 V 1866 do J. I. Kraszewskiego wspominał C. Norwid (w: jw., s. 451), że przygotowane do druku Vade-mecum znajduje się już u edytora: „rękpism jest opodal Ciebie, Szanowny Panie Józefie, bo u byłego mego wydawcy Brockhausa". 
związanej z napięciem między Prusami a Austrią ${ }^{11}$. W liście do Józefa Ignacego Kraszewskiego (pisanym na początku maja 1866), omawiając zawartość tomu Norwid podkreśla, że złożyć się nań miało nie tylko Vade-mecum, ale także „tragedia fantastyczna” Tyrtej Lacedemoński oraz „komedio-drama” Aktor ${ }^{12}$. I znów: nie sposób stwierdzić jednoznacznie, czy zarysowany przez poetę projekt edytorski był faktycznie uzgadniany z Brockhausem, czy to iluzoryczna wizja, ustalona na poczekaniu, wyłącznie - z trudnych do określenia powodów - w relacji z Kraszewskim, który miał przecież wydobyć rękopis Vade-mecum od lipskiego wydawcy już po zerwaniu z nim umowy. Nie możemy wykluczyć, że złożona zawartość tomu była faktycznie propozycja poety, która nie spodobała się Brockhausowi, co doprowadziło do konfliktu, a w efekcie do zakończenia współpracy.

Nie jedyny to i nie ostatni ślad starań Norwida związanych ze stworzeniem formuły i kształtu planowanego tomu. Na karcie autografu, gdzie znajdujemy motto zbioru, twórca nakleił kartkę z zapisem: „a Dorio, ad Phrygium” (VL 152). Bez trudu identyfikujemy go $z$ niedokończonym poematem Norwida o takim właśnie tytule, co nasuwa myśl o kolejnym składniku programowym planowanego tomu. Fert nie wyklucza, iż jest to „może podtytuł samego VM [tj. Vade-mecum]? A może to po prostu sentencjonalnie wyłuskana "definicja" dzieła?" (VL 152). Słusznie zastrzega zarazem:

Kiedy nastąiła ta zmiana? Nikt do dziś nie potrafi tego ustalić. Dodajmy jednak od razu, że nie da się też z całą pewnością stwierdzić, że znany nam - nieukończony - poemat „A Dorio ad Phrygium” stanowi (jak sugerował Zenon Przesmycki) potencjalne dopełnienie owego drugiego tomu Poezji, wprowadzone w miejsce planowanych wcześniej dramatów Tyrtej i Aktor. Niewątpliwie istnieją związki pomiędzy

11 Ten powód przywołuja Z. Trojanowiczowa i E. Lijewska (przy współudz. M. Pluty) w Kalendarzu życia i twórczości Cypriana Norwida (t. 2: 1861-1883. Poznań 2007, s. 249). Wprawdzie wojna między obu państwami wybuchła w czerwcu 1866 (trwała do końca sierpnia), ale już na przełomie lat 1865 i 1866 wiadomo było, że do takiego konfliktu dojdzie. W roku 1862 funkcję premiera Królestwa Prus objął O. von Bismarck, który otwarcie kontestował pozycję austriacką, dążąc zarazem do zjednoczenia Niemiec pod przewodnictwem Prus. Po wojnie z Danią (1864) sytuacja się jeszcze bardziej zaostrzyła między dawnymi sojusznikami, walczącymi o prymat w łonie Związku Niemieckiego. Zob. np. B. B o n d, The Austro-Prussian War, 1866. „History Today” 1966, nr 8. - E. D. Br o s e, German History 1789-1871: From The Holy Roman Empire to the Bismarckian Reich. Oxford 1997, zwłaszcza s. 329-363. - G. W a w r o, The Austro-Prussian War: Austria's War with Prussia and Italy in 1866. Cambridge 1997. W zachowanych dokumentach Norwida brak bezpośrednich danych, świadczących o tym, że sytuacja ekonomiczna wydawnictwa Brockhaus była niepewna lub niedobra. W pośrednich wypowiedziach poety - kierowanych do przyjaciół i znajomych (głównie Kraszewskiego) - nie można odnaleźć wprost wyrażonych powodów zerwania umowy. Poeta informuje twórcę Starej baśni na ten temat dość zdawkowo w liście z 5 V 1866. $Z$ kolei w liście pisanym tego samego dnia do H. Brockhausa, kierującego wówczas wydawnictwem, C. N orwid (w: Dzieła wszystkie, s. 455) prosi, aby rękopis „intitulé Vade-mecum à l'honorable J. I. Kraszewski à Dresde, selon son adresse”. Trudno tu zgodzić się z jednoznaczną sugestią autorów Kalendarza, że to Norwid wycofał się ze współpracy z lipskim wydawcą, zwracając się do niego, aby ten przekazał rękopis Kraszewskiemu. Owa prośba była raczej efektem już wcześniej zerwanej współpracy, o czym świadczyć może inne zdanie z cytowanego listu: „Je ne puis encore répondre à Votre dernière lettre [...]" (Norwi d, list do H. Brockhausa, s. 455). Brak odpowiedzi należy łączyć raczej ze wzburzeniem emocjonalnym, które spowodowane mogło być jakąś propozycją lub stanowiskiem Brockhausa w sprawie wydania (nie da się wykluczyć, że chodziło o wysokość honorarium). Warto przy tym zwrócić uwagę na lakoniczną formę wspomnianego pisma.

N o rwid, list do Kraszewskiego, s. 451. 
VM i „A Dorio”; w tym ostatnim znalazły miejsce co najmniej dwa - na nowo opracowane - utwory ze zbioru VM; na pewno wiersze XVII. Wieś (w. 225-252) i LV. Kótko (w. 354-373), no więc jak by się to miało do VM? Powtórzenie tych samych elementów podważa pomysł łączenia „A Dorio” z VM w jednym tomie. Nie ma więc dowodów na to, że tom drugi poezji postanowił Norwid w którymś momencie dziejów wydawniczych dopełnić poematem dygresyjnym „A Dorio ad Phrygium”, ba - wydaje się to wręcz nieprawdopodobne właśnie wobec wprowadzenia do tego ostatniego niektórych składników VM. [VL 152-153]

Z początkową częścią tej wypowiedzi wypada się całkowicie zgodzić: faktycznie, trudno rozstrzygnąć, czy chodziło tu o wspomniany nieukończony poemat (pytanie: nieukończony, a może znany tylko we fragmencie? - to osobna kwestia), czy też wyłącznie o zbieżność wykorzystanej formuły. Dyskusji nie podlegają także wykazane tekstowe pokrewieństwa niektórych fragmentów „A Dorio” z przynajmniej dwoma wierszami z Vade-mecum. Jednakże wyrażona w końcówce przytoczonego cytatu wątpliwość, czy artysta projektował wydanie poematu i zbioru 100 wierszy, ponieważ do tego pierwszego wprowadził składniki $z$ tego drugiego, nie wytrzymuje konfrontacji z praktyką pisarską Norwida. Układy powtórzeń i przetworzeń poetyckich, różnego typu repetycji oraz reminiscencji, opartych na podobnych tekstach lub ich fragmentach, pojawiaja się $\mathrm{u}$ autora Vade-mecum obficie, a ponadto owa „korespondencja” odbywa się nie tylko między różnymi utworami, ale także w obrębie jednego tekstu. Do tego drugiego przypadku należy zaliczyć poemat Quidam, w którym pieśni IV i V rozpoczynają się od fragmentu brzmiącego niemal identycznie, przynoszącego metaforyczny obraz walki świtu z nocą.

Zostawmy jednak dygresyjne rozważania na boku. Gotowy autograf-czystopis Vade-mecum Norwid dostarczył lipskiemu wydawcy. Gdy projekt edycji nie doszedł do skutku, kodeks wrócił do autora. Ten dalej czynił starania o opublikowanie zbioru wierszy. Natomiast manuskrypt Vade-mecum krążł wśród znajomych Norwida (pisze on o tym np. w liście do Ludwika Nabielaka z 2 IX 1869 〈PW-9 419〉). Bodaj ostatni ślad zabiegów poety o druk odnajdziemy w liście do Augusta Cieszkowskiego z 20 VII 1878 ( $(\mathrm{PW}-10$ 118-119); ślad to - przyznajmy - watpliwy, bo tytuł zbioru nie pada, a jedynie można go wydedukować pośrednio $z$ dotychczasowej korespondencji Norwida). W tym okresie autograf Vade-mecum - niechybnie za sprawą poety - zmieniał swój wygląd. Pierwotnie był to zapewne dość starannie zapisany czytelnym pismem kodeks. Nieliczne skreślenia obwodził autor konturem i wypełniał rytmicznym szrafowaniem. Kompozycyjne podziały utworów (ich strof) miały wybitnie graficzny układ, bardzo czytelny i klarowny. Jednakże - jak podkreślał w komentarzu Borowy:

$Z$ biegiem czasu zmieniał się [...] wygląd autografu, a przynajmniej pewnych jego części. Poeta wracał do niektórych utworów i poddawał je przeróbkom. Kreślił w nich wiele, wpisywał odmiany - ale już nie $z$ dawną starannością: teraz jakby dopadał tylko rękopisu i rzucał na papier pośpieszne notatki: jakby tylko dla samego siebie. Prawie wyłącznym narzędziem tych notatek jest ołówek [!] - czarny, czerwony, fioletowy, najczęściej niebieski, czasem bardzo gruby, jakby ciesielski. Proszę spojrzeć np. na Ogólniki (za wstęp), na Addio (VII), na Lirykę i druk (VIII), na Ciemność (IX), na Sieroctwo (XXIV) albo na Saturnalia (XXVIII).

Inne utwory spotykały się z innym losem. Wydobywał je poeta ze zbioru i wcielał jako części składowe do innych dzieł, później uplanowanych. Tak wiersze Wieś (XVII) i Kótko (LV) włączył z odmianami do poematu A Dorio ad Phrygium [...]. Podobnie wiersz Czemu (LXXXIV) wszedł z odmianami do komedii Miłość-czysta u kapieli morskich (napisanej wedle Miriama w latach 1877-1881), a z innymi odmianami do noweli Stygmat (1883). [VB XIII-XIV] 
Autograf Vade-mecum, który wysłał Norwid do Brockhausa - jako czystopis i dzieło skończone - nie odpowiada współczesnemu stanowi jego zachowania, nie tylko z powodu przeróbek i zmian. Otóż w stosunku do formy pierwotnej ta obecna ma zasadnicze braki, które trudno wyjaśnić. Czy karty z tekstami usuwał sam poeta, który po nieudanych staraniach wydawniczych wykorzystywał zawarte w kodeksie zapisy, pożytkował je gdzie indziej, czy też za owe ubytki odpowiadaja inne osoby? A może do zmian doszło już po śmierci Norwida? Trudno jednoznacznie orzec. W manuskrypcie brak kart, na których zrazu znajdowały się utwory o numerach porządkowych (każdy bowiem $\mathrm{z}$ tekstów miał taki numer $\mathrm{w}$ Vade-mecum: XXI-XXIII, XLVI-XLVIII, LVIII, LXIV-LXVII, LXXVI). Dwa wiersze (XXXIII i LIV) przepadły $z$ ich tekstem wraz $z$ kartami oderwanymi od zasadniczego kodeksu. Osiem utworów zachowało się jedynie we fragmentach: pozbawione albo początku, albo końca, albo środka. Dodajmy, że tylko nieliczne wiersze z Vade-mecum doczekały się publikacji za życia Norwida.

Z niecodziennym stanem rękopisu, który w początkowym etapie był kompletnym czystopisem, by $z$ biegiem lat stać się zdekompletowanym brulionem, wiąże się zasadnicze wyzwanie, $z$ jakim przychodzi się mierzyć każdemu edytorowi. Kwestią najważniejszą w przypadku omawianego zbioru nie jest czytelność przekazu - problem oczywiście dotyczy tzw. brulionowych poprawek - który w warstwie czystopisowej nie nastręcza takich trudności, jak np. Hrabina Palmyra, Kleopatra i Cezar lub nawet Rzecz o wolności słowa. W zakresie modernizacji ortografii, interpunkcji, podkreśleń, antycypacyjnych znaków zapytania czy pisowni dużych oraz małych liter na ogół poruszamy się tu w obrębie dobrze rozpoznanego w norwidologii tekstologicznego obszaru. W przypadku podkreśleń bądź strategii operowania dużymi literami raczej powinno się tu mówić o ascetycznym podejściu Norwida. Nie wydaje się także, by w warstwie przestankowania, a w konsekwencji stopniem komplikacji składni, interesujący nas zbiór dorównywał Guidamowi lub ostatnim nowelom. Za nieporozumienie edytorskie należy uznać podnoszoną co pewien czas kwestię odrębnego systemu interpunkcyjnego, który Norwid miałby wprowadzić na potrzeby omawianego zbioru. Najsilniej w tę stronę zwracał się Fert w przygotowanej przez siebie edycji Vade-mecum w serii „Biblioteka Narodowa”, gdzie we wstępnych deklaracjach podkreślał:

Znamieniem najbardziej uderzającym jest zasadnicza odrębność Norwidowskiej notacji zarówno wobec tradycji dawnej, jak i jemu współczesnej; dzisiejsze zasady interpunkcyjne również nie przystają do tego dzieła. Co dziwniejsze, ta interpunkcja sprawia wrażenie jednorazowego wynalazku, dokonanego ze względu na VM i więcej - w pełnym wymiarze - nie wykorzystywanego. Dość porównać VM np. z „A Dorio ad Phrygium” - a szczególnie te utwory, które znalazły się w obu dziełach - aby się przekonać o niepowtarzalności VM. Utwory sprzed VM również wykazują taką różnicę ${ }^{13}$.

Skoro ta interpunkcja miałaby być czymś odrębnym, to gdzie szukać reguł czy zasad wyznaczających i charakteryzujących tę odrębność. Jeśli odrębność, jak chce tego uczony, rysuje się np. w relacji do utworu „A Dorio ad Phrygium”, to pojawia się pytanie o wykaz owych dystynktywnych cech Vade-mecum. Pytanie o odmien- 
ności musi w takich przypadkach dotykać konkretnych, odrębnych cech. Nikt jednak ich nie formułował i nie określał, a przecież domena interpunkcji doskonale z tym koresponduje. Dlaczego nie udało się wyznaczyć zespołu cech odróżniających pod względem przestankowania Vade-mecum od innych dzieł poety, choćby od wspomnianego poematu? Odpowiedź wydaje się oczywista: bo takiego zespołu reguł nie ma. Odrębność Vade-mecum w zakresie interpunkcji po prostu nie istnieje! Ciekawe, iż w kolejnych edycjach zbioru Fert zrezygnował z cytowanego właśnie fragmentu, a zarazem $z$ tej ryzykownej konstatacji: równocześnie w przypadku wydania zbioru Norwida w serii „Skarby Biblioteki Narodowej” ${ }^{14}$, jak i wspomnianej wcześniej edycji lubelskiej.

Jednakże wyszczególnione przed chwila elementy są (jakby to ująć?) tekstologicznym drobiazgiem w porównaniu ze sprawą zasadniczą dla Vade-mecum. A mianowicie $-z$ wyborem podstawy. Ktoś, oczywiście, mógłby zadać pytanie: gdzie tu jest problem?! Dysponujemy przecież tylko jednym przekazem - autografem, znajdującym się w zbiorach Biblioteki Narodowej, szczęśliwie uratowanym $z$ wojennej pożogi m.in. przez wspomnianego tu już Borowego. Tekst do tego nie został wydany za życia Norwida. Zachował się autograf, więc on jest tu podstawą. Teoretycznie nie stajemy przed jakimkolwiek dylematem czy wyborem. Teoretycznie! Otóż to ogólne wskazanie nie rozwiązuje problemu, właśnie ze względu na koleje losu rękopisu oraz zmiany, jakim poddawał go sam Norwid, działający pod presją rozmaitych okoliczności. Choćby to, że - raz jeszcze przypomnijmy - z czystopisu manuskrypt zmienił się w zdefektowany brulion (na ogół mamy do czynienia $z$ sytuacjami odwrotnymi), powoduje poważne komplikacje. Jak bowiem rozpoznać ostatnią intencję twórcy, obowiązującą każdego wydawcę, w stosunku do całości zbioru oraz poszczególnych tekstów Vade-mecum? Trzeba pamiętać i o innym równie istotnym postulacie, a mianowicie: podstawa musi być jak najbardziej poprawna i staranna ${ }^{15}$.

Możliwe są tu - jak się wydaje - dwa skrajnie różne rozwiązania. Pierwsze każe traktować obecny stan rękopisu, ze wszystkimi zmianami, uzupełnieniami, prze-

14 Wydanie to, zgodnie $\mathrm{z}$ wyrażoną na tzw. stronie redakcyjnej nota, ,jest oparte na publikacji Zakładu Narodowego im. Ossolińskich - Wydawnictwo, z roku 1999, Seria I "Biblioteki Narodowej", nr 271" (F e r t, wstęp w: Norwid, Vade-mecum $\langle 2003\rangle$, s. 4).

15 Silnie podkreślał to K. Górski (Tekstologia i edytorstwo dzieł literackich. Warszawa 1975), wskazując, że z jednej strony trzeba mieć na uwadze fakt ulepszania dzieła przez autora (nawet po wydaniu), a z drugiej - poprawność i doskonałość tekstu: „Tak było np. z tekstem Werthera, obranym przez samego Goethego za podstawę nowego opracowania utworu dla wydania zbiorowego w r. 1787-1790 - Werther był wielokrotnie przedrukowywany bez kontroli autora i Goethe wzią za postawę nowego rękopiśmiennego opracowania jedno z najgorszych wydań swego dzieła. W ten sposób przedostały się do tekstu Werthera liczne skażenia, powtarzane w edycjach następnych" (ibidem, s. 89). Sztywna reguła faworyzująca wydania pierwsze lub ostatnie publikowane za życia autora nie zawsze jest słuszna i najszczęśliwsza. Przykładem może być edycja Dzieł wszystkich J. Koc ha now s ki e go (Wyd. Sejmowe. T. [0]: Wprowadzenie wydawnicze do edycji [...]. Oprac. M. R. Mayenowa, J. Woronczak, M. Kaczmarek, E. Głębicka. Wrocław 1983, s. 45. BPP, B 22), gdzie redakcja orzekła, że tzw. pierwsze wydania utworów pisarza są na ogół „najbliższe ręki autora” (zawierają mniej błędów niż późniejsze), ale niekiedy odstępowano od tej zasady, uznając inne, istotniejsze motywacje wyboru podstawy. Zwracano uwagę przede wszystkim na poprawność tekstu, na jego zgodność z tzw. wolą autorską. Jednym słowem: zasada wyboru przekazu najwcześniejszego nie była tu zasadą bezdyskusyjną. 
kształceniami, jakich dokonał Norwid, za ostateczna postać dzieła. W tym sensie formę brulionu - nieważne, czy uznawana za finalną, czy za swoisty rodzaj „dzieła w ruchu" - zrównujemy z wolą autorską. Edytor zobowiązany jest przecież do oddania ostatniej intencji artysty. Sprostanie temu wyzwaniu nie należy jednak do rzeczy łatwych. Borowy stwierdził wręcz: „Odczytanie niektórych - późnych - odmian wydaje się niepodobieństwem" (VB XX). Poprawki poeta sytuował zazwyczaj nad tekstem, czasami, gdy brakowało miejsca, wykorzystywał inne puste przestrzenie danej stronicy. Nieraz trudno z owego chaotycznego układu nowych rzutów, zapisów, ulepszeń i nie wykończonych pomysłów wydobyć linię przebiegu koncepcji twórczej. Zadanie staje się tym bardziej złożone, im więcej napotykamy - a takie przypadki nie należą do rzadkości, jeśli chodzi o brulionową warstwę Vade-mecumfraz, wyrażeń, wyrazów przemazanych, gdzie Norwid wpisuje jedną wersję na drugiej. Na szczęście, miejsc o nikłym stopniu czytelności, spowodowanej niedbałym, umownym lub pośpiesznym pismem, nawarstwianiem się słów na sobie albo jeszcze z multiplikowaniem tych wszystkich cech na niewielkiej przestrzeni (ich zsumowaniem), nie ma zbyt wiele, ograniczają się one rzeczywiście do kilku wierszy bądź pojedynczych wyrazów i zwrotów. Tak np. dzieje się w Addio! (w. 4 strofy 2: „pr $\langle$ aw $\rangle$ da s $\langle$ łow $\rangle$ a” $\langle$ VA 7v $\rangle$ ), Ciemności (w. 1 strofy 4: nieczytelny wyraz nadpisany na „i słowa” (VA 9r)), Saturnaliach (w. 3 poprawiony: pojawia się trudny do odczytania wyraz we fragmencie „Lub takiej kłótnei [---] natury:”, zanotowany na marginesie obok przekreślonego wersu, oraz w. 3 strofy 2 , z nieczytelną redakcja nad ,jestem" 〈VA 17r 〉), Czemu nie w chórze? (między w. 1 a 2 strofy 4 mamy z kolei nieczytelny, skreślony fragment pierwopisu 〈VA 16r)) czy w Śmierci (w. 2 strofy 3: na końcu wersu pojawia się zatarty atramentem wyraz lub jakieś bliżej nie zidentyfikowane litery 〈VA 42v〉). Nieliczne są również przypadki, gdy wyszczególnione tu kłopoty z odczytaniem i prześledzeniem procesu twórczego dotyczą stref o znacznie większym zakresie.

Za jeden z najbardziej zawiłych wierszy, który sprawia wiele problemów edytorom-analitykom, należy uznać Za wstęp. (Ogólniki). Pierwotna, kaligraficzna wersja jego tekstu, sporządzona atramentem, wyglądała tak:

\section{1.}

Gdy, z wiosną życia, duch Artysta,

Poi śie jej tchem jak motyle;

Wolno mu mówić, tylko tyle:

„Ziemia, jest kragła - jest kólista!”16

2.

Lecz, gdy późniejszych chłodów dreszcze

Drzewem wzruszą i kwiatki zleca;

Wtedy dodawać trzeba jeszcze:

„U biegunów, spłaszczona, nieco...”

3.

Po nad wszystkie wasze uroki,

Ty! poezjo i ty, wymowo;

16 W funkcji podkreślenia zarówno w cytatach z autografu Vade-mecum, jak i z Dzieł wszystkich N orw i d a wyjątkowo pozostawiono - zgodnie z edycja lubelską - kursywę. 
Jeden - wiecznie będźie wysoki:

$\mathrm{x} \times \mathrm{x} \times \mathrm{x} \times \mathrm{x} \times \mathrm{x} \times \mathrm{x} \times \mathrm{x} \times \mathrm{x} \times \mathrm{x} \mathrm{x}$

Odpowiednie dać rzeczy, słowo! [VA 3v]

Widać wyraźnie w autografie redakcję późniejszą: poeta wykonywał poprawki zwykłym ołówkiem i niebieską kredką. Trudno przy tym stwierdzić, które $\mathrm{z}$ nich są wcześniejsze oraz czy faktycznie rodzaj użytego materiału sygnalizuje dwie odmienne redakcje. Otóż poprawka w w. 3, gdzie słowo „Głosić” zostało napisane niebieską kredką na początku na ołówkowej poprawce „mowić”, mogłaby zaświadczać o redakcyjnej przewadze kredki nad ołówkiem, a jednocześnie o uznaniu tzw. poprawek niebieskich za editio definitiva. Ową wykładnię potwierdza poprawka w dodatkowych wersach - traktowanych przez niektórych edytorów jako projekt nowej strofy: mamy tu napisane jakieś słowo niebieską kredką (deszyfrowane przez Stanisława Makowskiego jako „Do *zakończenia” ${ }^{17}$, choć trzeba zauważyć, że stopień pewności w tego typu przypadkach należy uznać za wyjątkowo nikły) na innym słowie, zanotowanym ołówkiem. Ale z kolei dopisany diakrytyczny znak „niebieski” nad „Z” w wyrazie „będzie”, który to wyraz następnie poeta przekreślił ołówkiem, można potraktować jako świadectwo odmiennego trybu uszeregowania poprawek: najpierw kredka, dopiero później ołówek.

Kolejność i rezultaty zmian, a także liczba wyłaniających się redakcji, nie są tu aż tak ważne. Bardziej istotne wydaje się znalezienie punktu ostatecznego ukształtowania utworu Za wstęp. (Ogólniki). Już na początku Norwid nakreślił ołówkiem między w. 1 a 2 podwójną linię (między „życia” a ,jak”) ${ }^{18}$. Ani Przesmycki, ani Borowy nie odczytywali owego znaku jako sygnału projektowanej zmiany ${ }^{19}$. Odwrotnie postępowali późniejsi edytorzy, tekst zaś w tym miejscu po rekonstrukcji przyjmował postać:

Gdy, $\mathrm{z}$ wiosną życia, jak motyle;

Poi śię jej tchem duch Artysta

Jeszcze bardziej złożony wydaje się redakcyjny układ dwu początkowych wersów strofy drugiej. Poeta dokonał tu szeregu dość skomplikowanych ołówkowych zmian i korekt o charakterze brulionowym. Już w inicjalnym wersie przekreślił atramentowe „Lecz” oraz „gdy”. Nad usuniętym spójnikiem wprowadził ołówkiem „Ale”, następnie nadpisał nad nim ponownie „Lecz”. Przekreślił atramentowe „poźniejszych chłodów dreszcze”, a powyżej zanotował (ołówkiem): „Nawałne gdy przemina”, oraz poprawił rdzeń rzeczownika „dreszcze” na „deszcze” („esz” nadpisał na „resz”). Skreślił też kaligraficzne „Drzewo wzruszą”, przy czym inicjalny rzeczownik pierwotnie miał formę narzędnika, który poeta zastąpił biernikiem, poprawiając końcowe „em” na „o”. Przypuszczalnie, zamieniając przypadki, dopisał w tym czasie zaimek wprowadzający „Gdy”. Fragment brzmiał zatem na pewnym etapie tak:

S. M a k ow s ki, Nowa redakcja „Ogólników” Cypriana Norwida. „Przegląd Humanistyczny” 1986, nr 3/4, s. 161.

18 Wbrew sugestiom M. Grabowskiego (w: C. Norwid, „Vade-mecum”. Transliteracja autografu. Oprac., wstęp M. Grabow ski. Łódź 2018, s. 30) linia nie jest granatowa, ale ołówkowa. Poeta w przypadku wiersza Za wstęp. (Ogólniki) prócz atramentu wykorzystał w warstwie brulionowej wyłącznie ołówek oraz niebieską kredkę.

Zob. C. No rwi d, Za wstęp. (Ogólniki). W: Reszta wierszy odszukanych po dziś, s. 45. - VB XX. 
"Gdy Drzewo wzruszą” (z niepoprawioną dużą literą w „Drzewo”, choć prawdopodobnie $z$ intencja wymiany majuskuły na minuskułę). W końcu wszakże Norwid skreślił jednym pociągnięciem ołówka ten poprawiony zapis.

$\mathrm{W}$ obu interesujących nas wersach strofy drugiej, podobnie jak w przypadku dwu początkowych wersów strofy pierwszej, pojawia się w warstwie brulionowej linia łącząca pierwszą część w. 5 (tj. w. 1 strofy 2) z drugą częścią w. 6 (czyli w. 2 strofy 2): biegnąca od rzeczownika „puchy”, który został dopisany ołówkiem nad przekreślonym, zanotowanym pierwotnie atramentem, przymiotnikiem liczby mnogiej „późniejszych”, do rzeczownika „kwiatow” (jego końcówka „-ow” nadpisana na atramentowym „-tki” $\rightarrow$ „kwiatki”). Po zmianach te wersy brzmią następująco:

Lecz skoro puchy kwiatow zleca,

Nawalne gdy przeminą deszcze

Dość czytelne i oczywiste zmiany warstwy brulionowej strofy trzeciej, jak np. nadpisanie przymiotnika „mnogie” nad skreślonym „wszystkie”, zastosowanie przestawni: „dać rzeczy” $\rightarrow$ „rzeczy dać”, prowadzą do nowej redakcji tego fragmentu i zarazem nowej, zapewne późniejszej, redakcji brulionowej tekstu. Borowy nawet nazwał ją wprost „ostatecznie obowiązująca” (VB XX), choć - jak wspominałem podając jej brzmienie - uznał redaktorską zamiennię fragmentów w. 1 i $2 \mathrm{w}$ strofie drugiej, ale jednocześnie nie respektował podobnej zamienni w strofie pierwszej (edytor kursywą zaznaczył miejsca zmienione):

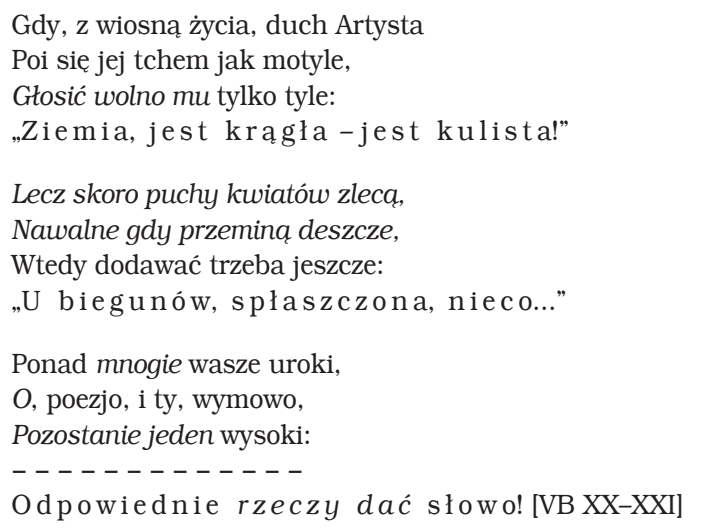

Zmianę w dwu pierwszych wersach korygowali kolejni wydawcy, przede wszystkim Gomulicki oraz Fert, umieszczając tzw. brulionową redakcję wiersza w strefie nowych wersji tekstu. Największy kłopot sprawiała edytorom strofa dołączona do trzech już istniejących (lub stanowiąca gruntowną odmianę którejś z nich). Stopień jej czytelności jest dość nikły, pismo zaś ma tu charakter wybitnie brulionowy. Borowy podkreślał, iż jej „wyczytanie zdaje się niemożliwością”, zastrzegając zarazem: „Co jednak wydaje się nie do odczytania przez jedno oko, może być szczęśliwie odczytane przez inne" (VB XXI). Ta uwaga uczonego padła na podatny grunt. Przez lata edytorzy i interpretatorzy wiersza Za wstęp. (Ogólniki) podsuwali bowiem różne rozwiązania. Swoje odczytanie zaproponował nie tylko Juliusz Wiktor Gomulicki:

Ten zostanie sercem i głowa.

Wharmonie * wziętej * spadkiem... 
I zawoła już * wódz na nowo...

Ludzie (...) koło... [DZ-2 176] ${ }^{20}$

- ale także Zdzisław Jastrzębski:

Ten zostanie sercem 〈?〉 i głową

W harmonię użytym jedną 〈?〉

I zawoła jak wódz na nowo

$[\ldots \ldots \ldots]^{21}$

- Stanisław Makowski:

Ten zostanie sercem i głowa

W harmoniczną użytym spójnię

I *zaczęta jak *wprzód na nowo

Do *zakończenia *będziesz *trwać - *ty!...22

- a nadto Józef Fert:

Ten zostanie sercem i głową

W harmonię ujętym jedną

I zawita jej ład na nowo

[. . . . . . . . $]^{23}$

Zdarzają się przypadki w autografie, gdy punktem spornym staje się usytuowanie wprowadzonych poprawek. Jak choćby w Sieroctwie, gdzie dopisane niebieska kredką dwa wersy umieszczono ( $\mathrm{z}$ odpowiednim odnośnikiem) w wolnym polu, poniżej kolejnego wiersza pt. Wakacje. Kłopotliwe było tu nie tylko ustalenie brzmienia dopisku, ale - jak się z czasem okazało - właśnie jego lokalizacja. Gomulicki dwukrotnie odczytywał interesujący nas dystych. W swojej pierwszej edycji Vade-mecum notował:

I jako struny wielkiej harfy jakiej,

Gdyby *.... brać $w$ rękę trunki ${ }^{24}$

W edycji Dziet zebranych - kilka lat po tamtym wydaniu - korygował zapis, zmieniając kolejność wersów:

Gdyby *... brać $w$ rękę trunki

Ijako struny wielkiej harfy jakiej [DZ-2 183]

Tej drugiej propozycji towarzyszył komentarz:

W ostatniej zwrotce [Norwid] poprawił jej wers pierwszy, drugi zaś i czwarty wykreślił, przy czym na przedłużeniu zamaszystej linii przekreślającej wers 2 dopisał jakiś niewyraźny wyraz, a u dołu karty, poniżej tekstu wiersza Wakacje, zanotował - do ewentualnego wykorzystania przy dalszej pracy

Kursywą edytor Dzieł zebranych wyróżnił teksty brulionowe „ukruszone, dochowane w przekazie budzącym zastrzeżenia, opublikowane bez podpisu autora [...] albo o podejrzanym autorstwie [...]" (DZ-1 144).

21 Z. J a s tr z ę b s ki, „Vade-mecum” upowszechnione drukiem. „Przegląd Humanistyczny” 1960, nr 2, s. $187-188$.

22 Makowski, op. cit., s. 161.

23 C. Norwid, Za wstęp. (Ogólniki). W: Vade-mecum (1990), s. 15.

24 C. Norwid, Sieroctwo. W: Vade-mecum (1962), s. 78. Edytor wprowadzając kursywę, sygnalizuje w tym wydaniu próbę nowej redakcji. 
warsztatowej - dwie nie związane ze sobą propozycje tekstowe, połączone z ostatnią zwrotką grubą linią kierunkowa (przekreślająca nb. tekst Wakacyj) [...].

Wyraz „trunki”, nakreślony przez $t$ „kokardkowe” [!], i to grubą niebieska kredką, robi wrażenie wyrazu „franki” (tak go też odczytali Terlecki i Jastrzębski; ten drugi wysunął jeszcze ewentualność „fraszki”), co sprzeciwia się jednak i wymogom rymu (do „opiekunki”), i wymogom sensu, ani owe „franki” bowiem, ani "fraszki” nie przystają do koncepcji wiersza, w którym znalazłoby się jednak miejsce na szyderczy koncept o trunkach, których dobrze znane działanie mogłoby uspokoić niecierpliwych obserwatorów takiego postępu (cywilizacji), o jakim pisze w swoim utworze poeta. [DZ-2 182-183]

Fert z kolei rekonstruując brulionową wersje przekazu, opatrywał propozycję uwagą o poprawkach poety (wykonanych niebieską kredką): że są one „trudne do kompozycyjnego zharmonizowania”. A zatem przedłożona przez edytora „lekcja brulionu nie jest pewna” (VL 287). Ostatnią strofę Fert odnotował w następującym brzmieniu:

Dwie, a tak marne mając opiekunki,

Ludzkość w sieroctwie znikłaby głębokiém,

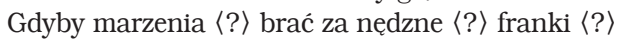

I jako struny wielkiej harfy jednej〈?〉 [VL 288]

Niedawno Mateusz Grabowski nie tylko uściślił przekaz spornego fragmentu, ale także uznał - z racją chyba najbliższą intencji autorskiej - że „wbrew lekcjom Gomulickiego i Ferta dystych umieszczony pod Wakacjami powinien znajdować się pomiędzy 1. i 3. wersem strofy V Sieroctwa":

\author{
Dwie, a tak błogie, mając opiekunki \\ Gdyby marzenia brać za nẹdzne franki \\ I jako struny wielkiej harfy jakiej \\ Gdyby, glób, niebył ramieniem piastunki, \\ Słońce?... jéj okiem!... ${ }^{25}$
}

Łatwiejsza wydaje się rzecz ze skreśleniami. A jednak i w takich przypadkach możemy mieć wątpliwości. Jeśli autor wykluczył zdecydowanym pociagnięciem wyrazy, zwroty czy nawet całe zdania, to nie powinny się one znaleźć w druku. W ich miejsce na ogół pojawia się nowa redakcja wykreślonego fragmentu. Jednakże od czasu do czasu natrafiamy na redukcje tekstowe pozbawione swoich stosownych ekwiwalentów - po prostu poeta nie daje w zamian innego nowego opracowania. Tak np. dzieje się z trzecią oraz czwartą strofą Liryki i druku. Zapewne intencją było w tym przypadku skrócenie tekstu, a aksjologiczny nośnik stał się miara kondensacji refleksji i poetyckości przekazu. O ile druga $z$ wykreślonych strof nie należy do najlepszych u Norwida, o tyle w perspektywie uwzględniania ostatecznych decyzji autorskich trudno byłoby się pogodzić $z$ utratą tej pierwszej (poniżej transliteracja tekstu rękopiśmiennego):

\author{
Treść, wypowiész bez liry udziału \\ Lecz dać duchowi, ducha, \\ Myśl, myśli - to, tylko ćiało ćiału: \\ Cóż z tego? Martwość głucha!.. [VA 8r] ${ }^{26}$
}

C. N orwi d, Sieroctwo. W: Vade-mecum. Transliteracja, s. 224, 223. Spacją zaznaczone są słowa zapisane niebieską kredką przez Norwida, linią ciagłą - jego podkreślenia, boldem zaś zasygnalizowano pogrubienia pochodzace od poety.

À propos tekstów dramatycznych lub narracyjnych - układ fabularny może niekiedy decydować 
Poważnym wyzwaniem są rekonstrukcje. Po pierwsze bowiem, określają one zakres i stopień umiejętności edytora: jego wiedzy na temat pisma i stylu poety; po drugie zaś - mogą być one pokusą badawczą, nie mniej groźną od ignorancji badawczej. Za jeden $z$ bardziej osobliwych i zarazem problematycznych należy uznać autograf Powieści. Liczne redakcje brulionowe, wprowadzone ołówkiem na pierwotną wersję kaligraficzną, sprawiają edytorom ogromne trudności. Wbrew wyrażonej przez Gomulickiego opinii strefa nieczytelności nie rozciąga się wyłącznie na obszar nowych pięciu wersów pierwszej zwrotki (najwięcej wątpliwości wzbudzają w. 5 i 6 : przekreślone, $\mathrm{z}$ nową redakcją i dopisanymi trzema kolejnymi wersami), zastępujących starą wstępną część tekstu, mieszczących się w autografie między zakończeniem Ironii a początkiem Powieści oraz przy górnej krawędzi VA 21r, ale dotyczy właściwie znacznej liczby innych zmian brulionowych wprowadzonych w wielu wersach interesującego nas tekstu $(4,14,17-18,20-21,31-32,34$ i 38). Brulionowy wariant Powieści pokazuje piętrzenie się problemów przed edytorem, który chciałby dochować zasady respektowania ostatniej woli autorskiej i jej owocu $\mathrm{w}$ postaci editio definitiva. Oprócz tego pojawiają się realne ograniczenia związane z czytelnościa przekazu, w tym przypadku warstwy brulionowej rękopisu wiersza. Dość powiedzieć, iż Gomulicki - nie bez słusznej racji - określa owe pięć wersów pierwszej strofy Powieści jako nieczytelną bazgraninę brulionową, „w której poszczególne wyrazy są albo zredukowane do pierwszych liter, albo tak skondensowane w zapisie, że poszczególne litery po prostu z nich powypadały" (DZ-2 186). Rzeczony fragment badacz odczytał, przygotowując swoje pierwsze autorskie wydanie Vade-mecum. Krytykę tego ustalenia podjął Jastrzębski: podważając przede wszystkim stopień pewności rozwiązań przyjętych przez edytora, zaproponował alternatywne zwroty i leksemy:

W pierwszej strofie nowej redakcji jest kilka lekcji niepewnych, np. słowo „krzyczą” można też odczytać jako: „krocza”, „kwicza”..., zaś „śmieja” to raczej „smuca”; tak samo niepewny jest „ślad na karcie” oraz „przezierał” (tu może „prosił”) i „Tom”, a „nań” winno być zastąione słowem „weń”. W strofie 3-ej wydawca samowolnie poprawił „przeprowadzonej” na „przeprowadzanej”, naginając poprawkę do słowa „wciąż", które jest lekcją b. wątpliwą. Wers ostatni może brzmieć: „Z dala za smętnym z powieści światem"27.

W tomie 2 Dzieł zebranych Gomulicki w charakterystycznym dla siebie stylu odrzucił większość wątpliwości Jastrzębskiego, wypominając swemu adwersarzowi m.in. brak wrażliwości na poezję, nieznajomość twórczości Norwida i jej właściwoś-

o potrzebie restytuowania tego, co autor zarzucił i pozbawił uzupełnienia. Trudno bowiem utrzymać w mocy takie zmiany, gdy w ich wyniku powstaje jakaś ewidentna luka narracyjna. Tak postępował np. J. Kl e i n e r (Układ i tekst dziet Stowackiego. 〈O pierwszym krytycznym wydaniu zbiorowym dziet poety . „Pamiętnik Literacki” 1909, z. 1/4) w przypadku brulionowego autografu Fantazego. Pisarz wykreślał niekiedy większe fragmenty tekstu lub nawet całe sceny, ale zarazem nie dawał nowych wariantów. Przywracanie tych starych broniło tkankę zdarzeniową przed niezamierzonymi lukami i przerwaniem ciagów. Zob. wstęp filologiczny do Fantazego autorstwa J. Czubka i J. Kleinera (w: J. Słow a cki, Dzieła wszystkie. T. 10. Lwów 1925, s. 189, 192-195) oraz wstęp do Fantazego wydanego w opracowaniu J. Czubka i J. Kuźni a ra, przy współudziale J. Kleinera (w: J. Słow acki, Dzieła wszystkie. Red. J. Kleiner. Wyd. 2. T. 10. Wrocław 1957, s. 126-134).

Z. J a strzę b ski, Poeta „bez wieńca i togi”. „Twórczość” 1963, nr 6, s. 60-61. 
ci, a także nieobycie się $z$ duktem pisma poety (zwłaszcza $z$ jego brulionowa postacią 〈DZ-2 187〉). Wyznając zasadę, iż najlepszą linią obrony będzie atak, edytor postanowił rozprawić się ze swoim niesfornym krytykiem, próbując zbić niemal wszystkie wysunięte przez niego propozycje, zupełnie nie dostrzegając prowokacyjności filologicznej zawartej w przedłożonej liście leksykalnych możliwościach. Jednak ta analiza krytyczna, mająca pokazać słabość enuncjacji wymienionych przez Jastrzębskiego, odsłoniła - niechybnie w sposób niezamierzony przez samego Gomulickiego - mankamenty użytej przez niego metodologii badawczej. W pewnym sensie owe rozbudowane, krytyczne względem Jastrzębskiego, analizy ujawniły warsztatową słabość ich autora, który ochoczo i zupełnie nieodpowiedzialnie wykorzystuje edytorstwo „natchnione”, zamiast sięgać po sprawdzone narzędzia filologiczne. Odrzucając zatem zaproponowaną przez Jastrzębskiego lekcje „kroczą” (miast „krzycza”), argumentuje:

nie przylega [!] ona do rymu „malowniczą” ani nie wiąże się z kontekstem, ani nie dorównuje swoją ekspresją artystycznemu poziomowi całego utworu. Jest ona po prostu nijaka, blada i nudna w swojej solenności. [DZ-2 188]

Rymy, ekspresja, ścisłość metryczna (czyli: „przyleganie”), a do tego „nijaka, blada i nudna" - tak jakby edytor zupełnie zapomniał o tym, że mamy do czynienia nie $z$ kaligrafowanym czystopisem, ale $z$ brulionem, co w innych miejscach stale podkreślał. Odmienny przykład stanowi choćby zakwestionowanie wysuniętej lekcji „prosił” zamiast „przezierał”: w autografie można rozpoznać „p” (lub najwyżej: „pr”) oraz - co także problematyczne - końcowe „ł”. W środkowej strefie czy też precyzyjniej: w strefie po „p” (,pr”), ciagnie się linia falista (co przyznaje sam Gomulicki). Prowadząc swój wywód założył, że poszukiwany wyraz powinien mieć trzy sylaby (ze względu na rytmikę wiersza) oraz z uwagi na najbliższy kontekst, że to czasownik z przesuniętą na początek wersu i odczytaną formą zwrotną. $\mathrm{O}$ ile wskazane tu tropy edytora uznać moglibyśmy za mniej lub bardziej pewne, o tyle nie wiadomo, dlaczego zarazem założył on, iż w owej nieczytelnej - a zatem nieoczywistej - strefie wyrazu nie powinny się znajdować litery z „laskami dolnymi” (np. „g”, ,j”) oraz „górnymi” (np. „k”, „”, „”, „t”). Skąd to przekonanie, że falista i umowna przecież linia (linia skrótu) nie może zawierać owych „lasek” (czyli wydłużeń górnych lub dolnych; pierwsze umieszczone są nad tzw. linią minuskułową, drugie to części liter schodzace poniżej ich linii bazowych)? Na tym etapie finał dowodzenia pseudoanalizy filologicznej jest nader osobliwy, ponieważ Gomulicki nawet nie sili się na maskowanie zasady wolnych skojarzeń w swoim postępowaniu:

Owocem owego śledztwa stała się niewielka garstka wyrazów, zredukowana następnie do ośmiu: „,ponawiat”, ,posuwat”, „pozierat”, „poznawat”, „pożerał”, ,przemieniat”, „przemierzał”, ,przezierat”. Każdy z owych wyrazów był kolejno wpisywany i póty „przymierzany” do powiązanego z nim, a znajdującego się w następnym wersie „tomu” [...], póki sens takiego powiązania nie skojarzył się w umyśle badacza z jakimś autentycznym obrazem norwidowskim [...]. Otóż skojarzenie takie wystąpiło dopiero przy wyrazie „przezierał”, wprowadzonym w następstwie do tekstu brulionowej redakcji Powieści. [DZ-2 190]

Sposób działania Gomulickiego dowodzi braku sumienności filologicznej. Oczywiście, błędy metodologiczne są sprawą istotną, dotykają bowiem warsztatu edytorskiego i poprawności wybranej strategii postępowania epistemologicznego, jednakże wobec zasadniczej kwestii związanej z zagadnieniem podstawy teksto- 
logicznej Vade-mecum muszą one pozostać na marginesie głównego nurtu rozważań. Czynności badacza, motywowane skądinąd szlachetna potrzebą kompletności edytorskiej, napotykają zarazem poważny opór materii tekstowej - opór brulionowej warstwy przekazu. Kompletność staje się tu wartością nadrzędną i najwyższą. W imię jej realizacji pewność odczytania jest zastapiona przez domysł, a prawda badawcza kapituluje pod naporem rozmaitych funkcji utylitarnych.

Wymienione przykłady związane z Sieroctwem, Powieścią czy wiersze Za wstęp. (Ogólniki) dowodnie pokazuja - i to od dziesiątków lat - że wybór brulionu jako podstawy wydania w przypadku Vade-mecum ma swoje głębokie uzasadnienie, ale również poważne konsekwencje, $\mathrm{z}$ którymi musi liczyć się każdy edytor, obierając tę drogę postępowania. Bez wațienia, uwzględnienie poprawek, skreśleń, uzupełnień stanowiących wyraźny dowód na zmianę zamysłu autorskiego wiąże się z respektowaniem zasady editio definitiva. Zarazem trzeba pamiętać, że brulionowy, niedomknięty charakter tych zmian nie pozwala na pełna ich deszyfracje, nie wszystkie bowiem dają się odczytać lub zrekonstruować w sposób w miare pewny. W konsekwencji przyjętego założenia otrzymujemy tekst kanoniczny zawierający strefy w dużym stopniu nieczytelne oraz miejsca kompletnie nie odczytane. Tak wyglądałoby rozwiązanie, które za podstawe obiera korekty i uzupełnienia ujęte w trybie brulionowym, naniesione na tekst kaligraficzny, pierwotny.

Teraz spróbujmy zatrzymać się przy drugiej z wymienionych możliwości, gdy za podstawe przyjmujemy tekst kaligraficzny, czystopisowy. Za tym rozwiązaniem przemawia praktyka edytorska, nie tylko dotycząca Norwida: utrwalił ją choćby Juliusz Kleiner w przypadku Juliusza Słowackiego, a Konrad Górski sformułował nawet zasadę, że ,jeśli próba nowej redakcji nie została wykończona lub jest nieczytelna, wówczas obowiązuje redakcja pierwotna" ${ }^{28}$. Urzeczywistnienie wspomnianego rozwiązania postulował Borowy przy okazji wydania fototypicznego, choć było to możliwe dopiero dzięki edycji krytycznej przygotowanej przez Ferta. W wydaniach, które stanowiły pierwszą próbę realizacji - w ramach serii „Biblioteka Narodowa” oraz „Skarby Biblioteki Narodowej” - edytor wskazywał jedynie ogólnie (by nie powiedzieć ogólnikowo), że za podstawę tekstową przyjmował autograf Vade-mecum, nie deklarując przy tym, która jego warstwę: pełną czystopisową $\mathrm{z}$ naniesionymi poprawkami brulionowymi czy też wyłącznie tę pierwotną. Dopiero w toku lektury czytelnik mógł się zorientować, iż układem tekstologicznego odniesienia była wersja kaligraficzna, zwana także pierwotna. Natomiast poprawki brulionowe pojawiły się w postaci wariantów wierszy takich, jak np. Za wstęp. (Ogólniki), Addio!, Liryka i druk czy Narcyz. Fert postępował bardzo podobnie do wydawcy Pism wszystkich, przyjmującego prócz wersji prymarnych (najczęściej kaligrafowanych), również warianty dla wierszy zmienianych i przekształcanych przez Norwida, choć z kolei przypadek edycji Vade-mecum przygotowanej przez Gomulickiego wymaga osobnego omówienia (wrócę do tej kwestii w dalszej części artykułu). Dopiero natomiast w wydaniu krytycznym Vade-mecum z 2004 r., opracowanym przez Ferta, znajdziemy wyraźna deklarację, że za podstawę tekstu całego zbioru przyjęto czystopis

28 K. Górski, rec.: C. Norwid, Vade-mecum. Wydał z autografu, uzupełnił i wstępem poprzedził J. W. Go mulicki. Warszawa 1962. „Pamiętnik Literacki” 1965, z. 2, s. 619. 
autografu. Prowadziło to do decyzji, aby zakończenie wspominanego wcześniej wiersza Za wstęp. (Ogólniki) w zapisie dać czytelnikowi jako kanoniczne:

Ponad wszystkie wasze uroki -

Ty! poezjo, i ty, wymowo -

Jeden - wiecznie będzie wysoki:

Odpowiednie dać rzeczy - stowo! [VL 11]

- rezygnując zarazem $z$ formuły chyba nie gorszej:

Ponad mnogie wasze uroki,

O, poezjo, i ty, wymowo,

Pozostanie jeden wysoki:

Odpowiednie rzeczy dać słowo! [VL 201]

Albo w jednym z fragmentów Liryki i druku, gdzie o znaczeniu „liry” dla pieśni poeta powiada w ten sposób:

Liry - nie zwij rzeczą w pieśni wtórą!

Do przygrywek!... nie - ona

Dlań jako żywemu orłu pióro -

Aż z krwią, nierozłączona! [VL 21]

- a nie jak w zgodzie z późniejszymi poprawkami:

Liry, nie wiń, że pieśni wtórą!

Do przygrawek że ona -

Ona jak żywemu orłu pióro;

Aż z krwią, nierozłączona! [VL 243]

Wybór wersji kaligraficznej mierzy się z krytyką, która towarzyszyła tej strategii niemal od samego początku zmagań wydawców $z$ tekstem Vade-mecum. Formułowała ją niegdyś zdecydowanie Zofia Stefanowska w stosunku do pierwszej edycji zbioru w opracowaniu Gomulickiego, zwracając uwagę na cytowany właśnie fragment wiersza jako symptomatyczny w kontekście wyłaniających się wątpliwości ogólnych:

I otóż tu moja wątpliwość, czy tam, gdzie nie można odtworzyć kompletnie wersji drugiej, należy przy ustalaniu tekstu kanonicznego zrezygnować z wszystkich poprawek stanowiących, bądź co bądź, wyraźny dowód zmiany autorskiego zamysłu. Czy wydawca nie posuwa rygoryzmu filologicznego zbyt daleko, gdy ustalając tekst podstawowy Liryki i druku np. ignoruje niewątpliwe poprawki autora tylko dlatego, że nie wszystkie dadzą się odczytać i zrekonstruować w kształcie skończonym. Równa się to decyzji, aby czytelnikowi dać do ręki tekst, w którym o znaczeniu „liry” dla pieśni powiedziano, że „Dlań jest jako żywemu orłu pióro”, nie zaś zgodnie z późniejszymi poprawkami: „Onajak żywemu orłu pióro”29.

Przyjmując wersję kaligraficzną zbioru, edytorzy niekiedy pozwalali sobie na odstępstwa od przyjętej reguły. Tak działo się zwłaszcza w przypadku Fortepianu Szopena, gdzie wyraźnie późniejsze poprawki naniesione ołówkiem uznawano za uzupełnił i wstępem poprzedził J. W. G o m uli c ki. Warszawa 1962. „Nowe Książki” 1963, nr 1, s. 68 . 
część wersji kaligraficznej, a nie brulionowej. Dopiero w edycji krytycznej Fert zrezygnował z owej praktyki - czy słusznie? (przyjdzie jeszcze dalej o tym powiedzieć) przyporządkowując zmiany do warstwy wtórnej. Przyjął więc w. 35 utworu w formie: "Jakby która starożytna Cnota" (VL 126), miast uwzględnić przestawnię wersji ołówkowej: „Jakby starożytna która Cnota”; w. 46: „Wzięta pieśnią zachwytu” (VL 127), zamiast: „Wzięta tęczą zachwytu”. Tak samo w w. 78, gdzie zachował zapis: „Pszenicznych ziarn dészcz prószy -” (VL 128), rezygnując z poprawionej jego postaci: „Dészcz pszenicznych ziarn prószy,” (oczywiście, zmiany interpunkcyjne w klauzuli rzeczonego wersu nie były tu dziełem autorskim, ale modernizacją wydawcy). Konsekwencję edytor zachował nawet wówczas, gdy lekcja kaligraficzna brzmiała gorzej od poprawionej ołówkiem. A tego rodzaju sytuacja zaistniała w przypadku w. 99, który pierwotnie wyglądał następująco: „Podobny sprzęt do trumny" (i taka wersję znajdziemy jako tekst podstawowy w wydaniu Ferta z r. 2004 〈VL 128〉). Norwid postanowił zmienić pozycję dwu wyjściowych wyrazów tego fragmentu, wysuwając rzeczownik przed przysłówek - zmiany dokonał ołówkiem. Początkowo nową redakcję zaznaczał zapisując cyfry nad wyrazami: „2” oraz „1”, następnie skreślił sygnał przestawni, notując, przed „Podobny”, na marginesie „Sprzęt” i zarazem skreślając ten sam wyraz po przysłówku. Fert, zobowiązany własną decyzją o wyborze podstawy, zrezygnował z ewidentnie lepszej formy wersu: „Sprzęt podobny do trumny”, lepszej zwłaszcza w zestawieniu z najbliższym otoczem, choćby w sensie rytmicznym. Miał zresztą pełną świadomość konsekwencji związanych $\mathrm{z}$ wyborem, czego efekt stanowi jego refleksja odnosząca się do opracowania tego wiersza. Fert pisał: „wersja czystopisowa, jak się nam wydaje, pod względem artystycznym ustępuje w kilku miejscach "brulionowi»" (VL 163) ${ }^{30}$.

Przy formułowaniu uwag na temat Fortepianu Szopena, dotyczących jakości zmian autorskich, trzeba koniecznie odnotować awers owego mechanizmu. Zdarzają się bowiem sytuacje - równie liczne jak te pierwsze - że dopisek lub jakakolwiek inna korekta zacierają efektowność dotychczasowego rozwiązania, co oczywiście mogłoby być wykorzystywane, gdyby nie casus przywołanych przed chwila poprawek z Fortepianu Szopena, jako argument na rzecz wersji kaligraficznej. Zakończenie wiersza Źródło wypada nadzwyczaj okazale. Kwestia włożona w usta „męża”, którego sylwetkę cechuje rodzaj szaleństwa lub nawet spersonalizowanego zła, wybrzmiewa wieloznacznym i zarazem złowieszczo-ironicznym akordem (oto transliteracja autografu):

\section{Patrzćie... jak Duch-stworzenia obówie mi czyści...! [VA 49v]}

Zmiana to dopisany, a właściwie wciśnięty między przywołany wers a tytuł następnego utworu, Historyk, komentarz dydaktyczny, zdecydowanie osłabiający siłę tamtej wypowiedzi (podaję wersję transliteracyjną autografu):

I depcąc zrudło butem, pluskał i na wieki

Depcąc je klął. [VA 49v]

30 Stosunkowo niedawno, publikujacc osobny druk Fortepianu Szopena (Kielce 2010), A. Ce d r o zrezygnował z tej kaligraficznej wersji, przyjmując za podstawę, jak to określił: „rękopis drugiej redakcji utworu" (ibidem, s. 20). 
Za pełną realizację wydania, które zgodnie ze wskazaniem Górskiego (był on zwolennikiem takiego rozwiązania) ${ }^{31}$ wzięło autograf Vade-mecum w jego redakcji kaligraficznej, czyli jako czystopis zbioru przeznaczony do druku, należy uznać przede wszystkim edycję krytyczną w opracowaniu Ferta z 2004 roku. Czy to zamyka cały problem? Nie do końca. Nadal bowiem pewne kwestie pozostają otwarte, a przynajmniej domagają się bliższego doprecyzowania. Fert składając deklarację na temat podstawy tekstowej, wskazywał:

Jest nią czystopis VM przygotowany dla Brockhausa, z uwzględnieniem „woli autorskiej” w zakresie działań wyznaczonych przez ramę czasową prac nad czystopisem, czyli nad tą postacią rękopisu dzieła, jaką autor na początku kwietnia ostatecznie przeznaczył (i przekazał) lipskiemu wydawcy - Brockhausowi. [VL 162]

Gdybyśmy dysponowali kompletnym czystopisem - jak powiada edytor - przygotowanym dla Brockhausa, to sprawa byłaby oczywista, ale przecież tak nie jest. Pamiętajmy, że część tekstów (zapisanych na kartkach przyklejonych następnie do kart kodeksu) bezpowrotnie, w niewyjaśnionych okolicznościach, zaginęła. Obiekt, którym dysponujemy, nie jest zatem takim samym obiektem (a przynajmniej obiektem w tym stanie), który trafił w ręce Brockhausa. Nie jest - jak chciałby edytor „postacią rękopisu dzieła, jaką autor na początku kwietnia ostatecznie przeznaczył (i przekazał) lipskiemu wydawcy [...]". Po raz kolejny przypomnijmy: sporo tekstów wierszy bezpowrotnie zaginęło, $z$ bliżej nie wyjaśnionych przyczyn. Nie rozwijam innej jeszcze kwestii, która aż prosi się - może w odmiennych okolicznościach o jakiś komentarz. A mianowicie: skąd niezłomna pewność wśród edytorów, że autograf (zdefektowany, pozbawiony części tekstów), którym obecnie dysponujemy, jest tożsamy z autografem Vade-mecum otrzymanym przez Brockhausa? Czy faktycznie Norwid posłał ten właśnie kodeks do Lipska? Ten aktualnie przechowywany w zbiorach Biblioteki Narodowej, w jej tzw. części skarbcowej? Takie pytanie można postawić choćby w obliczu projektowanych przez Norwida kolejnych wydań zbioru w różnych konfiguracjach: jako tekstu samodzielnego lub stanowiącego element większych układów kompozycyjnych (np. wraz z Aktorem i Tyrtejem czy poematem „A Dorio ad Phrygium”).

Wróćmy jednak do zasadniczego toku refleksji. Dlaczego Fert - choć dotyczy to także innych wydawców, w tym również Borowego - unika określenia i wskazania, w jaki sposób można w autografie rozpoznać i wyróżnić jego czystopisową wersję, jeśli chodzi o użyte narzędzia i materiały? Bez wątpienia, kaligraficzny porządek tekstu wyznaczony jest przede wszystkim przez zapis atramentowy, porządek zaś brulionowy wiąże się z rozmaitymi typami ołówków (zwykły, chemiczny) oraz kredek, głównie niebieskiej. Otóż - jak podkreśla Borowy - Norwid przygotowując swój skrypt dla wydawcy, „Liczby rzymskie, którymi oznaczone są poszczególne utwory, pociagał [...] czerwonym lub niebieskim ołówkiem” (VB XIII). Uściślam: pierwotnie cyfry te zostały zapisane atramentem. Mamy tu pewną rozbieżność logiczną. Zwracam uwagę, że niebieską kredką używaną do brulionowych poprawek (np. w przypadku wiersza Za wstęp. 〈Ogólniki〉) posłużył się również poeta korygując zakreślone wcześniej atramentem liczby rzymskie przy poszczególnych utworach zbioru. 
Raz zatem owa kredka staje się sygnałem brulionowej pracy, a kiedy indziej stanowi o kaligraficznym porządku tekstu - tak to przynajmniej można wyczytać u Borowego. To oczywiście drobny niuans, świadczący jednak o swego rodzaju niezdecydowaniu i braku logiki w rozróżnianiu owych rękopiśmiennych warstw przekazu.

Pytanie o granice rozdzielająca warstwę czystopisowa od brulionowej jest w pewnych przypadkach dość zasadnicze, odpowiedź zaś niejednoznaczna. Myślę tu np. o Fortepianie Szopena. Poprawki korektorskie wykonane ołówkiem Gomulicki odczytywał jako obowiązujące wydawcę, choć zarazem trudno bezwzględnie orzec - bo na ten temat edytor milczy - do której $z$ wymienionych warstw je zalicza. Fert z kolei włączył je (podobnie jak Gomulicki) do wydania „Biblioteki Narodowej”, lecz nie ujął w tym z r. 2004, co w obliczu jasnej deklaracji związanej z uznaniem przez Ferta czystopisu za podstawę świadczy, że traktował je tutaj jako poprawki brulionowe. Ale czy słusznie? Żaden $z$ edytorów nie przedstawił zdecydowanego dowodu na to, iż tekst atramentowy to tekst czystopisowy, a inne materiały: kredka, ołówek, są wyłącznie i bezwzględnie domeną brulionowości. Większość wymienianych wcześniej poprawek ołówkowych w Fortepianie Szopena pokrywa się z pierwodrukiem wiersza, który ukazał się w Piśmie zbiorowym, ,wydanym staraniem i nakładem Towarzystwa Naukowego Młodzieży Polskiej w Paryżu" ${ }^{32}$, przypuszczalnie zanim rękopis Vade-mecum trafił do Brockhausa. Istnieje prawdopodobieństwo, że Norwid nanosił te poprawki równolegle (niemal w tym samym czasie). Co każe uznać je za przynależące do tzw. tekstu pierwotnego. Ale poeta mógł je zrobić zaraz po tym, gdy ukazał się pierwodruk. Mógł także wprowadzić je znacznie później, nawet po powrocie przesyłki rękopisu zbioru $z$ Lipska. Każda $z$ potencjalnych interpretacji sytuuje przekształcenia redakcyjne po stronie czystopisu. Fert nie bez racji podnosił jeszcze inną ważną kwestię, a mianowicie autorstwa owych poprawek: „Trudno jednak z całą pewnością stwierdzić, że wszystkie poprawki ołówkowe wykonał sam Norwid” (VL 534). Gdyby uznać, iż faktycznie przynajmniej część z tych zmian nie została skreślona ręką poety - bez względu na ich zbieżność z pierwodrukiem - wówczas tylko wersję atramentową zapisu należałoby traktować jako obowiązującą.

Po stronie czystopisu staje także tradycja edytorska. Nigdy nie wydano tekstu Vade-mecum na podstawie autografu $\mathrm{z}$ uwzględnieniem brulionowych poprawek poety. Żaden z edytorów nie zdecydował się na ten wariant, w którym - jak to określał Borowy - chodziło o respektowanie ostatniej intencji (woli) Norwida, choć precyzyjniej należałoby mówić tu o działaniach autorskich. Trudno bowiem z ocalałej wersji rękopisu ową wolę wysnuć. Dlaczego wydawcy nie decydowali się na taki wariant, w pewnym sensie naturalniejszy i właściwszy od tego, który za podstawę bierze tekst kaligraficzny? Czyżby nikt nie uznawał walorów tekstologicznych tego tropu edytorskiego? Sądzę, że odrzucenie takiego rozwiązania miało raczej charakter pragmatyczny. Wydawanie tekstu $z$ wersji kaligraficznej jest łatwiejsze niż wydawanie $z$ wersji brulionowej: ten drugi wariant zakłada przecież mocowanie się 
z przejrzystością przekazu, licznymi dylematami związanymi z jego deszyfracja, brakiem pewności, aprobowaniem miejsc, które nie zostaną odczytane.

Nietrudno zorientować się, że edycje Vade-mecum opracowane i przygotowane przez Gomulickiego (począwszy od r. 1962, a skończywszy na osobnym wydaniu ,lubelskim" z r. 1984) stanowily w toku wywodu negatywny wzorzec. Dlaczego? Otóż nie mieszczą się one w żadnym $z$ dwóch zaprezentowanych tu rozwiązań. Edytor zresztą unika jednoznacznych deklaracji: czy za podstawę bierze wersję kaligraficzna autografu czy może punktem odniesienia są dla niego poprawki brulionowe wprowadzone później? W Pismach wszystkich te wskazania dotyczące wyboru podstawy sformułowano bardzo ogólnie: „Tekst wg autografu w kodeksie VM [...]” (PW-2 378). Podobnie jest w najobszerniejszym komentarzu edytorskim w ramach 2-tomowych Dziet zebranych: „Te k s t podstawowy [!] wg rękopisu-autografu [...]” (DZ-2 136). Dopiero w toku analiz - głównie związanych $\mathrm{z}$ kolacjonowaniem przekazu - można zorientować się w dokonanych przez Gomulickiego wyborach.

Przede wszystkim trudno rozpoznać tu jakąś konsekwencję i zasady. Edytor bowiem raz traktuje tekst kaligraficzny czystopisu jako ostateczny (taka opcja na ogół przeważa), poprawiony zaś, brulionowy, jako nową redakcję, a innym razem odwrotnie: kaligraficzny jako nieaktualny, natomiast ten skorygowany jako ostateczny. Przykładem pierwszego rozwiązania może być opracowanie wiersza Za wstęp. (Ogólniki). Przy realizacji tej opcji Gomulicki odrzucił wszystkie poprawki brulionowe, pozostawiając wersję czystopisową. $Z$ kolei przykład drugiego - zupełnie odmiennego - sposobu rozpatrywania stanowi opracowanie Fatum, gdzie brulionowa poprawka w pierwszym wersie, wykonana niebieską kredką, została uwzględniona w późniejszych wydaniach Vade-mecum przygotowywanych przez Gomulickiego: „Jak dziki zwierz przyszło [...]” (zob. np. DZ-1 583; PW-2 49), a nie jak w wersji kaligraficznej: „Jak zwierz dziki przyszło [...]” (VA 18r). Jakie są kryteria tych niecodziennych rozwiązań? Trudno rozpoznać. Wydaje się, że decyduje o nich wola edytorska, uzbrojona wyłącznie w słuch poetycki, a nie stosowne argumentum philologicum. I na tej woli opiera się postanowienie, aby w tekście Przeszłości przyjąc poprawki w w. 4: „wspomnienie” $\rightarrow$ „spomnienie”, oraz w w. 5: „Lecz” $\rightarrow$ „Acz” (nadpisane i skreślone) $\rightarrow$ „Acz” (dopisane), jednocześnie zaś odrzucić podobne zmiany w w. 9: „Przeszłość, jest to dźiś, tylko cokolwiek daléj:” $\leftarrow$ „Przeszłość, jest, i dziś i te dziś daléj:" - są one w autografie zupełnie czytelne. Wszystkie corrigenda poeta wykonał przecież atramentem, tym samym, którym zapisał cały tekst wiersza: trzeba więc uznać je za przynależące do warstwy kaligraficznej rękopisu. Autograf Przeszłości nie notuje bowiem zmian brulionowych, jak w przypadku wymienianego utworu Za wstęp. (Ogólniki). W tym sensie ustalenia Gomulickiego pozbawione są logiki - żaden edytor opracowując tekst Przeszłości nie staje przed jakimkolwiek dylematem, ponieważ odpada problem: uwzględnić czy odrzucić późniejsze poprawki poety? Respektować wersję czystopisową? A może respektować brulionowe zmiany? Mamy tu bowiem do czynienia wyłącznie z kaligraficznym zapisem, czyli wszelkie modyfikacje i skreślenia winny być wzięte pod uwagę. A znów w Addio! Gomulicki odczytał wszystkie poprawki, jednak uznał je za redakcje podrzędną wobec redakcji kaligraficznej. Redakcja kaligraficzna pojawiła się zatem w tekście głównym zbioru w Pismach wszystkich, tymczasem ta z poprawkami - w specjalnym 
dodatku z ostatnimi redakcjami i ostatnimi wersjami dziewięciu ogniw Vade-mecum. Co motywowało edytora? Skąd tak diametralnie odmienne sposoby podejścia do poprawek? Trudno orzec, wygląda, że - jak wskazywał Górski - u Gomulickiego decydował „osobisty gust, nie zaś konsekwentnie stosowana zasada edytorska”33. Ocena tego pierwszego (tj. Górskiego) to zresztą osobna kwestia, która edytorskim poczynaniom tego drugiego (czyli Gomulickiego) w kolejnych jego wydaniach Vade-mecum dodaje pikanterii. Otóż Górski już w 1962 r. opublikował w „Roczniku Literackim” - w postaci krótszej, następnie zaś w „Pamiętniku Literackim” w postaci obszerniejszej, bardzo negatywną, a właściwie wręcz druzgocącą recenzję edycji Vade-mecum w opracowaniu Gomulickiego. Krytyka miała charakter frontalny i fundamentalny: dotyczyła modernizacji pisowni, przyjętych rozstrzygnięć interpunkcyjnych, nieporozumień związanych z kwestią krytyczności, ale przede wszystkim podstawy tekstologicznej - dowolności i arbitralności w zakresie podejmowanych decyzji edytorskich.

Z biegiem lat szokowała nie tyle skala popełnionych błędów i uchybień, ile stanowisko Gomulickiego, który w kolejnych wydaniach Norwidowego zbioru jedynie część popełnionych (zwłaszcza w swoim pierwszym wydaniu) błędów korygował, lecz w ogólnych ramach kontynuował przyjętą strategię, pozostając na pozycjach wyznaczonych na samym początku własnej drogi edytorskiej. Tak więc np. w edycji z 1962 r. w przypadku utworów, które ukazały się drukiem w postaci innej niż czystopisowa, za tekst obowiąujący uznał tekst opublikowany, nie zaś manuskrypt. Postapił tak z Ciemnościa oraz z wierszem Echa-czasu (w autografie Vade-mecum: Saturnalia), posiłkując się pierwodrukiem nowej redakcji obu tekstów, ogłoszonych w „Echu” w r. 1877 (nr z 1 I) ${ }^{34}$. Z tych pomysłów edytor wycofał się już przy okazji wydania Vade-mecum w ramach Dzieł zebranych, a następnie potwierdził przyjety kierunek w Pismach wszystkich. Podobnie poczatkowo postępował z utworami, które poeta włączał do swoich nowszych dzieł: podawał je w formie ostatniej wersji. Stąd Kótko czy Wieś pojawiły się w edycji zbioru z 1962 r. na podstawie tekstu „A Dorio ad Phrygium”, nie zaś autografu Vade-mecum. Natomiast Czemu opracował Gomulicki w oparciu o późny Stygmat, gdzie wiersz ten stanowi tekst pieśni Oskara, bohatera noweli. Jako równie kuriozalny należy potraktować pomysł, by restytuować tekst brakującego w rękopisie ogniwa LIV - znanego tylko z zachowanego tytułu Jak - korzystając $z$ jednego $z$ fragmentów dopiero co wymienionego poematu. Nawet gdyby owa hipoteza była wielce prawdopodobna, to wciąż otwartą kwestia pozostaje sprawa granicy „wyciętego” tekstu. Do tego dochodzi, oczywiście, dość osobliwa koncepcja swobodnego przemieszczania urywka późniejszego do wcześniejszej struktury kompozycyjnej. O ile z pomysłów redagowania Kótka, Wsi oraz Czemu Gomulicki rychło się wycofał, zmieniając teksty podstaw wierszy w Dziełach zebranych, o tyle jego bardzo kontrowersyjne stanowisko w stosunku do utworu Jak nie zmieniało się, w pełni utrwalone w Pismach wszystkich.

Górski, rec., s. 619.

Autografy wierszy przesłane redaktorowi pisma uchodza za zaginione. K. Ko pc zyński (Próba interpretacji „Ciemności”. W zb.: Język Cypriana Norwida. Materiaty z konferencji zorganizowanej przez Pracownię Stownika Języka Norwida, w dniach 4-6 listopada 1985 roku. Red. K. K o p c zy ński, J. Puzynina. Warszawa 1990, s. 135) zaznaczał, analizując tekst Ciemności, że wersja Z „Echa” zawiera błędy, a przez to, , jest to przekaz najmniej ze wszystkich czterech autentyczny”. 
$Z$ podobnym zamieszaniem i brakiem konsekwencji mamy do czynienia w przypadku tych wierszy z Vade-mecum, które złożyły się na odrębny zbiór zatytułowany Co słychać? Co poczaćć Przypuszczalnie powstał on później niż Vade-mecum. Gomulicki uważa, że w r. 1876, ale jego domniemanie stanowi wyłącznie hipotezę, do tego nie poparta jakąś stosowną dokumentacją (PW-3 775-776). Zaginiony rękopis Co słychać? Co poczać? to 6-kartkowy, cienki zeszyt (były to trzy złożone na pół i zszyte arkusze). Tekst znany jest jedynie $z$ odpisu, sporządzonego przez Przesmyckiego (oryginał należał do Wacława Gasztowtta i znajdował się w Paryżu) ${ }^{35}$. Właśnie ów odpis stał się podstawą do kontrowersyjnych rekonstrukcyjnych działań Gomulickiego. W wydaniu Vade-mecum z 1962 r. niezachowaną w autografie końcową część Prac-czoła edytor uzupełnił, wykorzystując wspomniany zbiór i zamieszczony w nim fragment Co poczać?, który bez watpienia był innym wariantem Prac-czoła. Wystarczy jednak przywołać oraz porównać początkowe i końcowe wersy obu przekazów, aby się przekonać, jak ogromnie ryzykowne były to zabiegi:

"Pracować-muśisz" głos ogromny woła
Nie z potem dłoni lub twojego grzbietu
(Iż prac-poczatek, doprawdy że nie tu)
Pracować musisz z potem twego czoła!

(Prac-czoło, VA 34r; transliteracja)

Co począć?... nie tu, zaiste, że nie tu

Poczatek dzieła - głos odwieczny woła:

„Pracować musisz!” - i nie z potem grzbietu,

Lecz „Z potem CZOŁA”...

(Co poczać?, PW-3 631)

Spustoszałemu powiedz Narodowi

Niech się zbogaći jak może najprędzéj

A mając posag, resztę postanowi,

(Prac-czoło, VA 34v; transliteracja)

Tak, zniszczonemu rzeknij narodowi,

By się zbogacał tylko jak najprędzéj,

A złoto mając resztę postanowi,

(Co poczać?, PW-3 632)

Nie tylko jednak ostatni fragment zakończenia wiersza Prac-czoło został poddany prawom dość osobliwej rekonstrukcji. Praktyka ta rozciagała się na całe utwory: Co stychać? czy Krzyż i dziecko - których autografy nie zachowały się w kodeksie Vade-mecum-Gomulicki przeniósł ze wspomnianego zbioru Co słychać? Co poczać? Za równie dowolną i skąpo uzasadnioną należy uznać decyzję, aby Tymczasem, wiersz zapisany po stronie verso kartki $\mathrm{z}$ autografem Obojętności (VA k. luźna, przyklejona do VA 17v kodeksu), zaliczyć w poczet utworów Vade-mecum, do tego zaś wyznaczyć ściśle jego pozycję w zbiorze: edytor doszedł do wniosku, iż Obojętność powinna znajdować się między Specjalnościamia Sieroctwem. Uważał, że zabieg taki jest możliwy i nawet wręcz pożądany, wymaga tylko dobrze uzasadnionej identyfikacji konkretnych utworów spoza Vade-mecum, wydawanych o czym była mowa - później lub włączanych do innych tekstów, „Z odpowiadający- 
mi im, a brakującymi, ogniwami owego zbioru [...]" (PW-2 377), wyjaśniał badacz. $\mathrm{W}$ jaki sposób natomiast uwiarygodniał tę niecodzienną $\mathrm{z}$ punktu widzenia edytorstwa operację? Otóż wskazując, że zbiór Norwidowski jest świadomie ułożonym, skomponowanym cyklem, Gomulicki starał się odkryć zasadę owej kompozycji. W edycji pierwszej z 1962 r. ujmował kolejność utworów w ramy dwutematowości każdego $\mathrm{z}$ nich: temat drugi jakiegoś tekstu stanowił zarazem temat pierwszy tekstu następnego, itd. Wymieniane przez edytora tematy-klamry stawały się w istocie efektem subiektywnych (emocjonalnych) lektur odbiorcy, a nie filologicznym argumentem, podlegającym regułom dedukcyjnym. W Pismach wszystkich Gomulicki wskazywał jeszcze na układy tematyczne oraz ideowe - równie prawdopodobne i weryfikowalne jak te pierwsze. Stąd w metryce utworu Tymczasem znajdziemy znamienne wyjaśnienie:

Tekst [...] na odwrocie wlepionej tam [tj. w rękopisie Vade-mecum] kartki z tekstem wiersza Obojętność [...]. Właściwe miejsce tego wiersza, który musiał się znajdować na jednej z zaginionych kart kodeksu VM, zostało wydedukowane na podstawie jego ścisłego sklamrowania $z$ wierszem Sieroctwo [...]. [PW-2 383]

Ten wątpliwy mechanizm przenoszenia tekstów bądź ich fragmentów z późniejszych odpisów lub edycji dość trafnie sam edytor przedstawił przy rekonstrukcji ostatnich wersów utworu Prac-czoło w swoim pierwszym wydaniu Norwidowskiego zbioru (na szczęście, zrezygnował z niej w kolejnych edycjach: Dzieł zebranych oraz Pism wszystkich). Zwracam uwagę w poniższym cytacie na słowo „załatać”; użyte chyba nieco bezwiednie, dobrze charakteryzuje i postawę, i intencje Gomulickiego czy jego stosunek do zasadniczego obiektu jego zabiegów, jakim jest tekst:

Jeśli chodzi z kolei o szczerby, to można je częściowo załatać - i to niestety w minimalnym stopniu - jedynie w dwóch przypadkach: przy wierszu Prac-czoło (LXIII), którego urwany ostatni wers (z rymem) można było uzupełnić wg tekstu pierwszej wersji tego utworu z r. 1864, oraz przy wierszu Szlachcic (LXXII), którego początek, dłuższy o dwa wersy, znajduje się również na tzw. Karcie Paryskiej, czyli na zachowanej w papierach po Z. Przesmyckim zagadkowej karcie (BN III 6321, k. 288), na której nieznana ręka skopiowała cztery pełne wiersze VM, sześć drobnych ułamków czterech innych utworów tego cyklu oraz prozaiczny rodnik wiersza Źródło (XCIII), przy czym wszystkie owe utwory i ułamki zostały podane w ich wcześniejszym kształcie tekstowym. [PW-2 377]

Można pominąć kwestię odpisu, czasu, kontekstu bądź funkcji. Ale koniecznie należałoby zadać pytanie o cel takiego działania. Czy motywacja stała po stronie prawdy i szacunku wobec autora i jego spuścizny, czy też po stronie satysfakcji edytorskiej?

W znakomitej recenzji Dzieł zebranych, opublikowanej na łamach „Pamiętnika Literackiego", Zofia Trojanowiczowa zwróciła uwagę na jeszcze jedną osobliwą praktykę Gomulickiego: a mianowicie na zamieszczanie w tejże edycji utworów nieautonomicznych (wchodzących w skład innych tekstów lub zbiorów). Czyli i takich, których autonomię określił autor, i także takich, które usamodzielniły się wola edytora. W efekcie - zwłaszcza za sprawą Vade-mecum - niektóre wiersze były drukowane dwu- albo nawet trzykrotnie. Uczona wskazywała, że choć ta strategia poszerza zasób dokumentacji edytorskiej, to zarazem odsłania wiele słabości i momentów spornych:

Sztucznie zwiększa dorobek wierszopisarski Norwida, a równocześnie - dotycząc z konieczności wybranych tylko przypadków - nie oddaje w pełni pracy poety nad przystosowaniem wiersza do życia 
w zmienionym kontekście. Przykładowo - wiersz Saturnalia z Vade-mecum został opublikowany trzykrotnie: w redakcji kaligraficznej i w redakcji próbnej (w ramach cyklu) oraz w późniejszej redakcji autonomicznej pt. Echa-czasu, niewiele różniącej się zresztą od redakcji próbnej Vade-mecum. Ale: wiersz Obyczaje, włączony przez Norwida do Vade-mecum jako Sens-świata, następnie wkomponowany do humoreski Co słychać? i co poczać?, a później na nowo usamodzielniony pt. Szczęśliwy, zamieszczono w Dziełach zebranych dwukrotnie, z pominięciem ostatniej autonomicznej redakcji. Edytor nie odnotowuje przy tym przeróbek, które ostatecznie stały się udziałem wiersza. (Ktoś, kto chciałby się z nimi zapoznać, musi sięgać po Okruchy poetyckie i dramatyczne, w których z okazji publikacji wiersza Szczęśliwy - redakcja $z$ humoreski - edytor podaje warianty innych redakcji. Dziwna to jednak sytuacja, kiedy aparatu do edycji zbiorowej i nazywanej przez edytora krytyczną musimy poszukiwać w innym wydaniu. A nie jest to przecież wypadek odosobniony. ${ }^{36}$

A zatem znów powracają kwestia logiki działań oraz konsekwencje przyjętych rozwiązań.

Przypadek Gomulickiego nie został tu przywołany wyłącznie na prawach krytycznego spojrzenia na historię edytorskiego kształtowania się Vade-mecum, na które miał on przecież ogromny wpływ, przynajmniej do lat osiemdziesiątych ubiegłego wieku. Ten negatywny i zarazem osobliwy sposób patrzenia na Norwidowski zbiór mógłby - pod pewnymi warunkami - odsłonić swój pozytywny aspekt. Oczywiście, $z$ góry możemy odrzucić, uznając za niedorzeczne i błędne warsztatowo, wszelkie rekonstrukcje tu opisane, ale zastosowaną ogólną zasadę osobliwego podejścia do każdego $\mathrm{z}$ tekstów, do każdego $\mathrm{z}$ wierszy - już nie. Zaprezentowałem dotad bowiem dwa skrajnie odmienne sposoby wyznaczania podstawy tekstu Vade-mecum. Pierwszy traktował brulionowe poprawki jako przejaw ostatecznej decyzji autora. Drugi z kolei odrzucał je na rzecz wersji kaligraficznej przekazu - jako tej przygotowanej do druku i wysłanej przez Norwida do lipskiego wydawnictwa. Oba podejścia do zagadnienia odznaczają się pewnym maksymalizmem w zakresie praktyki wydawniczej. Oba także - choć nie ujawniają tego wprost - traktują zbiór Vade-mecum jako idealną całość. A ta całość przecież nie istnieje. Wersja kaligraficzna zakłada, iż mamy do czynienia $z$ autografem wysłanym przez Norwida do Brockhausa, choć poważny defekt wielu wierszy (zagubienia ich fragmentów lub nawet pełnych tekstów) sprawia, że w rzeczywistości nie dysponujemy kompletnym czystopisem. Respektowanie wersji brulionowej wiąże się z podobnym założeniem, edytor zaś zostaje skazany na działania w ograniczonym obszarze korektorskich poczynań poety. Ten swoisty dylemat, jaki rysuje się między stroną czystopisu a stroną brulionu, trafnie scharakteryzował Fert. Wymieniając w toku wywodu zdefektowane części manuskryptu oraz wskazując na grupę tekstów poddanych poprawkom i uzupełnieniom przez poetę, edytor podkreślał:

Teksty te to w istocie bruli ony redakcyjne. Prócz problemów grafologicznych, w większości już rozwiązanych, stawiają one wydawcę przed zasadniczymi i, zdaje się, nierozwiązywalnymi pytaniami, m.in. kompozycyjnymi, nie wiadomo przecież, czy poprawki te można traktować jako kolejne próby

Z. Tr oja n ow i c z, rec.: C. N orw i d: Dzieła zebrane. T. 1: Wiersze. Tekst; t. 2: Wiersze. Dodatek krytyczny. Oprac. J. W. Gomulicki. Indeksy zestawiła M. Gomulicka. Warszawa 1966. „Pamiętnik Literacki” 1968, z. 1, s. 304-305. Zob. też Z. Troj a n ow i c z, Uwagi o pierwszych dwóch tomach „Pism wszystkich” Cypriana Norwida w opracowaniu Juliusza Wiktora Gomulickiego. "Studia Norwidiana” t. 3/4 (1985/86). Przedruk w: Z. Troja nowicz, Romantyzm od poetyki do polityki. Interpretacje i materiaty. Wybór, red. A. Artwińska, J. Borowczyk, P. Śniedzi ew ski. Kraków 2010. 
nowych redakcji tłumaczacych się w koncepcji c ał e go zbioru VM, czy raczej jako jednostkowe przeredagowania pojedynczych tekstów, które tą drogą przeszły w inny porządek i inną chronologię dorobku pisarskiego poety, nie odnosząc się do całościowej struktury tego „cyklu” poetyckiego. [VL 168]

Jednakże Fert, podobnie jak i wielu wydawców, nie dostrzega innej drogi. Widzi wyłącznie owe skrajne stanowiska. A właśnie krytykowane podejście Gomulickiego naprowadza na trzecią z możliwości, choć - co trzeba zaznaczyć - naprowadza nie wprost. Warto wykorzystać dostrzegalną u wydawcy Pism wszystkich wariantowość ujęcia i płynące $z$ tej wariantowości zróżnicowanie metodologiczne. Było ono motywowane błędna potrzebą wypełniania i łatania miejsc pustych i niedookreślonych w autografie, kosztem obiektywnej prawdy o tekście. A przecież zabiegi edytorskie powinny sprowadzać się do jednego celu: wydania tekstu kompletnego, poprawnego - najbliższego intencji twórcy, wyrażonej wprost oraz immanentnie wpisanej w sam przekaz, a zatem możliwej do zrekonstruowania z różnych elementów i warstw kompozycji, struktury, stylu i języka przekazu. Jakkolwiek nie istnieje cały i pełny przekaz, istnieje wola autorska jego wydania: bądź jako edycji osobnej, bądź jako edycji, w której zbiór tych wierszy byłby jednym ze składników większej, bardziej złożonej publikacji, ale także w postaci integralnej i kompletnej. Czy nie należałoby zatem ze słuszniejszą racją rozpatrywać każdy $z$ wierszy oddzielnie, rozpatrywać jako osobny tekst, określając przy tym, co przyjmujemy za jego podstawę: wyłącznie warstwę czystopisową lub warstwę uwzględniającą brulionowe poprawki? Stąd $\mathrm{np}$. być może powinno się uwzględnić poprawki naniesione na kaligraficzny tekst Narcyza i uznać za zasadniczą redakcję brulionową? Tak, jak to uczynił Gomulicki w swoim pierwszym wydaniu w r. 1962, a z czego wycofał się w wydaniu Dzieł zebranych oraz Pism wszystkich, gdzie zmiany złożyły się na tzw. osobną próbę nowej redakcji wiersza, traktowana - czy chciał tego edytor, czy też nie chciał - jako podrzędna wobec redakcji głównej. Przypuszczalnie taka sama zasada, po odpowiedniej analizie, każe odrzucić niepełną nową redakcję Liryki i druku i zarazem przyjąć za podstawę jej wersję kaligraficzną. Oczywiście, istotnym motywem stałoby się tutaj określenie stopnia wykończenia i domknięcia poprawek i zmian. Czy intencją autora było uznanie ich za obowiazujące, czy też okazały się one na tyle nieskrystalizowane, na tyle robocze i „nie-gotowe”, że trudno byłoby je traktować w kategoriach wydawniczych (dopełnionych)? W ten sposób wychodzimy także naprzeciw ogromnemu zróżnicowaniu, jakie charakteryzuje cały zbiór Norwida: oprócz tekstów nietkniętych poprawkami, czystych i definitywnych, mamy przecież dość sporo wierszy i miejsc zawierających piętrzące się retusze i uzupełnienia, wiele z nich (jak np. poprawki bądź dopiski w Fortepianie Szopena lub w Fatum) nie jest znakiem „dzieła nie-gotowego" czy „dzieła w ruchu”, ale sygnałem wyrażonej woli i przejawem tzw. editio definitiva. Przedstawiona przed chwila propozycja maksymalnie redukuje niebezpieczne metody postępowania wobec tekstów, jakie prezentował Gomulicki, choćby w przypadku Przeszłości, gdzie arbitralnie jedne poprawki uwzględniał, a innych nie. Taki hybrydowy układ postępowania nie powinien mieć zastosowania z oczywistych powodów. Należałoby tu zarazem podkreślić, że ta elastyczna metoda (wariacyjna i otwarta wobec każdego $z$ wierszy) nie zaprzecza potrzebie oddania całości zbioru: w końcu chodzi o publikację Vade-mecum w postaci możliwie naj- 
pełniejszej, czyli takiej, jaka dotrwała do naszych czasów - w formie zdefektowanego autografu.

W końcowej części wywodu wróćmy raz jeszcze do wariantu, który uznaje autograf zbioru - w stanie takim, jak on obecnie wygląda - za ostateczną wersję i podstawę edycji Vade-mecum, ze wszystkimi brulionowymi poprawkami naniesionymi przez poetę. Rozwiązanie to nie znalazło swoich szczęśliwych wykonawców. Realizacja takiej bowiem edycji, która oddawałaby brulionowość Vade-mecum w formie tradycyjnego wydania, dotąd się nie powiodła. Warto wszakże zwrócić uwagę na wymienianą już podobiznę autografu Norwidowskiego zbioru w opracowaniu Borowego: przez wiele lat stanowiła ona jedyna kompletną edycję Vade-mecum. Ten wydawniczy start cyklu był dość symptomatyczny i zarazem symboliczny. Po latach do tego pobocznego nurtu tekstologicznego skutecznie powrócił, stosunkowo niedawno, Grabowski, publikując transliterację zbioru Norwida. W pewnym sensie w obu edycjach, które dzieli przecież długi, ponad 70-letni, dystans, należałoby upatrywać jakiejś próby realizacji owego brulionowego rozwiązania, ale równocześnie są one - a zwłaszcza propozycja Grabowskiego - zarysem zupełnie nowych możliwości. I po raz kolejny: podobnie, jak w przypadku Gomulickiego, punktem wyjścia pozytywnych rozwiązań byłyby ograniczenia i cechy negatywne podjętych starań edytorskich.

Wydanie Grabowskiego odznacza się sumiennością i starannością, zwłaszcza w miejscach, gdzie mamy do czynienia $z$ warstwą brulionową. Wszelkie działania filologiczne związane $z$ transliteracją wymagają przecież wytężonej uwagi i wierności wobec tekstu, który może stawiać silny opór. Nieczytelność zapisów, skreślenia i nawarstwianie się zmian, wprowadzanie nowych wersji na starych, wielokrotne realizowanie nowych wariantów, nieczytelność nowych wpisów, stosowanie rozmaitych materiałów (atrament, różne typy ołówków, kredka) - to tylko drobna lista problemów, z którymi musi mierzyć się filolog dokonujący transliteracji. Ale nawet czystopis może być tu wyzwaniem: spór o przysłowiowy przecinek niejednemu badaczowi spędzał sen z powiek, choćby wtedy, gdy trudno rozpoznać po latach, czy obiekt naszych zabiegów analitycznych stanowi fantomową przebitkę z drugiej strony karty, czy niewyraźny, bo wyblakły i utleniony pod wpływem czasu i warunków przechowywania, lecz rzeczywisty wpis. Niekiedy kłopotliwa staje się lokalizacja nowych, brulionowych wpisów. Mając na uwadze owe liczne pułapki i problemy edytorskie, dokumentację Grabowskiego należy uznać za udaną, wzbogacająca naszą wiedzę o rękopisie Vade-mecum: imponuje zwłaszcza pokaźna liczba nowych odczytań tekstu.

Oczywiście, niektóre przyjęte przez edytora rozwiązania mogą budzić zastrzeżenia, jak np. oddawanie skreślenia przez skreślenie, a nie utrwalone w dotychczasowej praktyce stosowanie odpowiednich ekwiwalentów graficznych, zwiększających jasność i czytelność przekazu ${ }^{37}$. Podobnie wątpliwe wydaje się zastosowanie -

37 Edytorzy często stosują w takich przypadkach nawias rozwartokątny. Zob. np. Wiersze Adama Mickiewicza $w$ podobiznach autografów. Oprac. Cz. Zgorzelski. Cz. 1: 1819-1829. Wrocław 1973; cz. 2: 1830-1855 (1998). - A. M i c ki e w i c z, Dziadów część III. [T. 2:] Transliteracje, ko- 
w zgodzie ze stanem rękopisu - kolorów przy uzupełnieniach, poprawkach czy redukcji jakiegoś fragmentu tekstu, które Norwid wykonywał czerwoną lub niebieską kredką, ołówkiem, atramentem. Gdyby edytor oprócz transliteracji opublikował barwne fotografie podobizny autografu, tego typu zabiegi, ciążące w kierunku dość nieoczywistej wierności ikonograficznej przekazu, straciłyby swoją funkcjonalną rację. Motywację wzbudziła tu bez wątpienia akrybia, której podstawą było narzucone wyzwanie: całkowitego i wiernego odwzorowania w druku stanu rękopisu. Trzeba wszakże pamiętać, że owo odwzorowanie nie jest celem transliteracji, lecz domena podobizn fotograficznych czy cyfrowych (np. skanów). Jak dalece Grabowskiemu zależy na wiernym odwzorowaniu graficznego wyglądu manuskryptu, niech świadczy gospodarowanie przestrzennym usytuowaniem przekreśleń: raz ich linie prowadzone są w druku środkową strefą zapisów, innym razem - w zgodzie $z$ oryginałem - zostają przesunięte ku górnym partiom, etc. Ale znów pojawia się wątpliwość: czy takie właśnie cele stawia sobie transliteracja? Może - zamiast odwzorowywać w druku wygląd autografu - należałoby elementy graficzne, jak linie, kreski, przekreślenia większych fragmentów tekstu, ujmować w tryb komentarzy filologicznych, lokując je w strefach opracowań (przypisów lub dodatków krytycznych)?

Jednakże największe wątpliwości, $z$ punktu widzenia omawianej tu problematyki, budza próby wychwycenia wielowariantowości, więcej: prezentowanie wielowariantowości w typie edycji, która powinna przecież literę oddawać literą, a znak znakiem. Starania związane $z$ wyłanianiem warstw tekstu stanowią domenę interpretacji i domysłu, których musi tu wystrzegać się opracowujący, przesuwając je do partii komentarza. W edycji Grabowskiego - co warto zaakcentować - widzimy nie tylko oddzielenie warstw kaligraficznej od brulionowej, ale rozmaite próby wydzielenia wariantów przekazu w obrębie samego brulionu. Ten ruch ku wielowarstwowości przekazu (czy też właściwie: przekazów) ma, oczywiście, swoją w pełni filologiczną i epistemologiczną motywację, choć jednocześnie - raz jeszcze należy mocno podkreślić - kłóci się z celem praktycznym, trybem i zakresem przyjętych czynności.

Główną motywacją w tropieniu i odsłanianiu wielowariantowości rękopisów wierszy Vade-mecum jest silne przekonanie Grabowskiego, wyrażone zresztą w Uwagach wydawcy, o komplementarności i aksjologicznej ekwiwalencji wersji tekstów. Zaznaczając, że tę kwestię Norwidowskiego zbioru zobaczył i zrealizował Gomulic-

mentarze. Oprac. ed. Z. St ef a n ow s ka, współpr. M. Pru s s a k. Warszawa 1998. Trzeba zarazem - w obronie Grabowskiego - stwierdzić, że współczesne badania dążą do zacierania granicy między transliteracją a transgrafią, rezygnując $z$ nawiasów na rzecz właśnie skreśleń, zob. np. „Raptularz wschodni” Juliusza Stowackiego. Edycja - studia - komentarze. T. 2: Edycja-komentarz - objaśnienia. Red. M. Kalinowska, U. Makowska, Z. Przychodniak, M. Tros zy ńs ki, D. Kaja. Warszawa 2019. Nieraz ten sam edytor w ciagu wielu lat stosuje oba rozwiązania. Zob. np. J. Sł ow a c ki, [Raptularz 1843-1849]. Pierwsze całkowite wydanie wraz z podobizna rękopisu. Oprac. ed., wstęp, indeksy M. Tros zyń s ki. Warszawa 1996. Gdy sięgniemy po opracowany przez uczonego Raptularz poety, to zauważymy, że badacz użył nawiasów rozwartokątnych jako sygnałów skreśleń. Ale z kolei w stosunkowo niedawno opublikowanej transliteracji manuskryptu Samuela Zborowskiego wykorzystał M. Tro s zy ń s k i (Alchemia rękopisu. „Samuel Zborowski” Juliusza Stowackiego. Warszawa 2017) „drukowane skreślenia”. 
ki, a następnie Fert, edytor jakby zapomniał zastrzec, iż ten pierwszy nie włączał „na równych prawach pierwotnych i ostatnich redakcji poszczególnych wierszy ze zbioru" do każdego swojego wydania ${ }^{38}$. Pojawiły się one w Dziełach zebranych, lecz w Pismach wszystkich przesunięto je do Dodatków, które usytuowano po zasadniczym tekście całego Vade-mecum. Podobnie drugi z wymienionych badaczy, czyli Fert: znalazł miejsce dla wariantów wierszy w tekście głównym w ramach edycji popularnych czy też popularno-naukowych (serie: „Biblioteka Narodowa” oraz „Skarby Biblioteki Narodowej”). Wszakże w wydaniu krytycznym z 2004 r. warianty znajdują się wyłącznie w odmianach i komentarzu, co wskazuje na silny rozdział między strefami kanoniczną i wtórną (czytaj: odrzucona). Tę strategię wymuszał jednoznaczny wybór podstawy (warstwa kaligraficzna autografu). Za niedorzeczne należałoby uznać przypuszczenie, że Norwid dążył do publikowania równoległych wariantów wierszy zbioru i że wydobyte - już nie przez poetę, lecz przez edytorów wersje miały imprimatur autorskie. Wszystkie okoliczności i starania Norwida (w tym także kaligraficzna wersja Vade-mecum) stawiaja pod znakiem zapytania takie interpretacje, krojone przecież na miarę postmodernistycznej, a nie XIX-wiecznej wrażliwości.

Próba uchwycenia przez Grabowskiego zmienności i dynamiki zapisów Norwidowskiego autografu - wykraczająca poza założony cel, czyli wydania drukiem transliteracji manuskryptu - prowadzi do jeszcze jednej możliwości, związanej z edycją Vade-mecum. Dodajmy: możliwości komplementarnej, a nie opozycyjnej wobec trzech dotychczas zarysowanych w zakresie wyboru podstawy. Chodzi mianowicie o edycję cyfrową Vade-mecum - edycję w przestrzeni Internetu. Od razu też zaznaczę, że nie należę do wielbicieli systemów w pełni otwartych i komplementarnych, które programowo uciekają od tekstów ustalonych krytycznie, od tego, co rozstrzygnięte i rozstrzygające ${ }^{39}$. Przy edycji cyfrowej Vade-mecum możliwe byłoby wypracowanie takiej struktury, która pozwalałaby: $z$ jednej strony, zadowolić popleczników tradycyjnego podejścia do tekstu, a z drugiej - byłaby akceptowalna dla przeciwników editio definitiva. Tych pierwszych musi usatysfakcjonować moduł zawierający editio optima, gdzie powinny znaleźć się trzy nakreślone przeze mnie drogi postępowania, związane $z$ wyborem podstawy, przy czym wydawca musiałby

Grabowski, wstęp w: N orwid, Vade-mecum. Transliteracja autografu, s. 20.

Nie czas tu na szczegółową polemikę z tym otwartym stanowiskiem, które z zasady chciałoby unikać tekstu definitywnie ustalonego na rzecz swoiście pojmowanego „dzieła w ruchu” czy też może raczej „ruchu dzieła” (albo wręcz: „ruchu w dziele”). Koncepcja edytora-intepretatora ustępuje miejsca koncepcji edytora-kustosza, potrzeba zaś dopełnienia i oddania definitywnej postaci tekstu - jego wersji niegotowej, wariantowej. Ciekawe, czy nawet wbrew sądom i opiniom twórcy, który zaplanował i wyraził jakąś określoną koncepcję swego dzieła? A to wszystko w imię wolności odbiorcy oraz edytora. Ten drugi nie musi więcej podejmować arbitralnych decyzji, ten pierwszy zaś - nie musi ich przyjmować. Dlaczego? Bo powinny zmienić się zasady i reguły: ten drugi, czyli edytor, nie jest już interpretującym egzekutorem nieokreślonej woli autorskiej, lecz jedynie organizatorem środowiska tekstowego (hipertekstu), ten pierwszy zaś, czyli odbiorca, dysponentem przekazanych mu środków i narzędzi. Zob. np. P. B e m: Dlaczego polskie edytorstwo naukowe nie istnieje. „Teksty Drugie” 2016, nr 1; „Zachować intencję autora”. O szlachetnym kłamstwie w edytorstwie naukowym. „Tekstualia” 2017, nr 1. - Ł. C y buls ki, Retoryka tekstologii. „Teksty Drugie” 2019, nr 2. Zob. też P. B e m, Dynamika wariantu. Miłosz tekstologicznie. Warszawa 2017. 
podjąc decyzję, która z trzech realizacji odpowiada - co wymagałoby najprawdopodobniej stosownego uzasadnienia - określeniu „optima”. Dwie pozostałe stanowiłyby wówczas równe sobie warianty, podrzędne wobec realizacji głównej. $Z$ punktu widzenia transliteracji Norwidowskiego zbioru przygotowanej przez Grabowskiego najciekawszy byłby niechybnie moduł drugi, dokumentacyjny ${ }^{40}: \mathrm{z}$ wprowadzonym do systemu autografem Vade-mecum (oczywiście, w wysokiej rozdzielczości), ze wszystkimi jego wydaniami oraz transliteracja (także transgrafią). Specjalny program - a jest to dziś całkiem osiagalne - mógłby wyodrębniać warstwy rękopisu. Edytor swobodnie operując programem oddzielałby najwcześniejszą postać kaligraficzną od brulionowej lub ją z nią łączył (tu też dałoby się wyróżnić kolejne warstwy, np. poprawki ołówkowe, od wykonanych niebieską kredka). Więcej jeszcze: można byłoby edytować poprawki atramentowe, m.in. „zaglądać” pod warstwy skreśleń czystopisowych. $Z$ pewnością zakres operacji byłby tu jak najszerszy, obejmowałby np. zestawienia fragmentów tekstów $\mathrm{z}$ odległych kart, separowanie pojedynczych wyrazów lub zwrotów - w celu dokonania analizy porównawczej. Należałoby także stworzyć stosowną bazę indeksową, zarazem lingwistyczną, jak i onomastyczną (oczywiście, ze swobodnym wyszukiwaniem). Kolacjonowanie powinno mieć przy tym charakter cyfrowy, co nie tylko skróciłoby czas takiej operacji, ale bez wątpienia uczyniłoby ją znacznie precyzyjniejszą. Zasady i reguły kolacjonowania (chociażby związane $z$ kolejnością zapisów) określiłby edytor w odpowiednim programie, już sama zaś czynność stanowiłaby wyłącznie domenę odbiorcy. Wykonalna w odpowiednim module trzecim: gdzie każdy użytkownik mógłby swobodnie postępować z tekstem, przekształcać go, zmieniać, lecz tylko we własnej, odrębnej domenie. Te operacje nie powinny wpływać na kształt modułu pierwszego, a tym bardziej drugiego. Moduł pierwszy miałby bowiem charakter stały, choć i tu możliwe byłyby weryfikacje i tworzenie nowych ustaleń (np. co 5 lub co 10 lat).

Niekiedy mówi się wprost przy edycjach cyfrowych o wydaniach dokumentacyjnych, które w pewnym sensie nawiązują do rozmaitego typu wydań transliteracyjnych oraz fototypicznych w świecie książki. Tego rodzaju edytorstwa domagała się M. Prussak (Konsekwencje założeń i decyzji edytorskich. „Teksty Drugie” 2005, nr 1/2), nazywając takie wydania, realizowane w formie cyfrowej, wydaniami dokumentacyjnymi. Taki sposób publikowania rękopisów, brulionów etc. odwołuje się bez wątpienia do postulatów formułowanych w końcu XX w. przez francuską krytykę genetyczną i jej koncepcję przed-tekstów - zob. O. D a w i d o w i c z-C hy m k o w s k a, Przez kreślenie do kreacji. Analiza procesu twórczego zapisanego $w$ brulionach dziet literackich. Warszawa 2007. - W. Kr u s z e w s ki, Rękopisy i formy. Badanie literatury jako sztuka odnajdywania pytań. Lublin 2010. - P.-M. de Bia si, Genetyka tekstów. Przeł. F. Kwiatek, M. Pru s sak. Warszawa 2015. - Archiwa i bruliony pisarzy. Odkrywanie. Red. M. Prussak, P. B e m, Ł. Cybuls ki. Warszawa 2017. Obecnie jednak zaznacza się tendencja poszerzająca pojęcie tekstu reprezentowane przez genetyków (na ogół kojarzyli go oni z drukiem) na materiały rękopiśmienne (zob. m.in. B e m, Dynamika wariantu). Zapewne wpływ na ten sposób traktowania i rozumienia tekstu mieli amerykańscy teoretycy-tekstolodzy (jak np. P. Shillingsburg, J. McGann, D. McKenzie czy J. Stillinger), do których chętnie odwołuje się współczesne pokolenie edytorów i teoretyków edytorstwa: ich podejście do zagadnienia - w odróżnieniu od genetyków - cechuje znaczna doza utylitaryzmu, różnorodnie motywowana i warunkowana. Zob. Ł. Cybulski: Krytyka tekstu i teoria dzieła. Jerome McGann wobec anglo-amerykańskiej tradycji edytorstwa naukowego. „Teksty Drugie” 2014, $\mathrm{nr} 2$; Krytyka tekstu na rozdrożach. Anglo-amerykańska teoria edytorstwa naukowego $w$ drugiej połowie XX $w$. Warszawa 2017. - P. B e m, Nowa bibliologia - nowa krytyka. Paradoksy relacji. „Teksty Drugie” 2015, nr 3. 
Drugi moduł - źródłowy, wiązałby się z czynnościami analitycznymi. Odpowiadałby na postulaty formułowane w ostatnich latach przez zwolenników edycji cyfrowych ${ }^{41}$, którzy kładą nacisk na podkreślenie wagi wszystkich przekazów tekstu oraz prezentację uwarunkowań towarzyszacych, niezbędnych przy edytorskiej lekturze: a zatem przekaz wysokiej jakości obrazów tekstu i transkrypcji/transliteracji/transgrafii. Powinien on być utrwalony czy też raczej opisany za pomoca języka znaczników, czyli XML (eXtensible Markup Language). Znaczniki pozwalają gdy w danym obszarze tekstu znajduje się przestrzeń wymagająca edytorskiej interwencji - asygnować je, opisać, odnieść do innego miejsca w tym samym przekazie lub w ogóle do nowego przekazu czy wręcz poza jakimikolwiek przekazami. Otwierają się tu ogromne możliwości w warstwie komentarza i zestawień, nawet takich, których trudno oczekiwać przy realizacji wydań książkowych ${ }^{42}$. W przypadku Vade-mecum w przestrzeni komentarzy powinny się znaleźć wersje tych wierszy, które wyszły spod pióra Norwida na długo przed powstaniem zbioru, oraz wersje opublikowane przez poete przy innych okazjach lub zapisywane przez niego znajomym. Przykładowo: pierwsza zachowana redakcja wiersza $W$ Weronie pojawiła się w utworze dramatycznym Noc tysiaczna druga (w formie beztytułowego fragmentu lirycznego ${ }^{43}$. Jako osobny tekst liryczny, pt. Nad grobem Julii Capulleti $w$ Weronie, został opublikowany na łamach „Pokłosia. Zbieranki literackiej na korzyść sierot" ${ }^{4}$. W roku 1860 kopię utworu Na grób Julietty - na podstawie nieznanego rękopisu - sporządził Teofil Lenartowicz w liście $z$ marca 1860 do Józefa Ignacego Kraszewskiego ${ }^{45}$. Kolejnym przekazem wiersza jest ten znany z kodeksu Vade-mecum jako $W$ Weronie (VA 7). $\mathrm{W}$ formie beztytułowego fragmentu lirycznego opublikowała go Zofia Węgierska na łamach „Biblioteki Warszawskiej” w 1867 r., w ramach prowadzonej przez felietonistkę Kroniki paryskiej ${ }^{46}$. Zapisany ołówkiem autograf zachował się w spuściźnie po Węgierskiej (znajduje się w Bibliotece Litewskiej Akademii Nauk im. Wróblewskich w Wilnie 〈BF 1947〉), na luźnej kartce

41 Zob. np. J. McGann, From Text to Work: Digital Tools and the Emergency of the Social Text. „Romanticism on the Net” 2006, nr 41/42. Na stronie: https://www.erudit.org/en/journals/ ron/2006-n41-42-ron1276/013153ar/ (data dostępu: 19 V 2020). - J. Mc Gann, D. Buzzetti, Critical Editing in a Digital Horizon. W zb.: Electronic Textual Editing. Ed. L. Bu rnard, K. O'Brian O'Keffe, J. Unsworth. New York 2006. Na stronie: https://tei-c.org/Vault/ ETE/Preview/mcgann.html (data dostępu: 19 V 2020). - M. M a ry 1, Technologie literatury. Wpływ nośnika na formę i funkcje przekazów literackich. „Pamiętnik Literacki” 2010, z. 2, s. 174-178. Ł. C y b u ls k i, Przełom cyfrowy w edytorstwie naukowym a problem rozumienia tekstu. Przyczynek do dyskusji. W zb.: Tożsamość tekstu. Tożsamość literatury. Red. P. B e m, Ł. Cy bulski, M. Prus s a k. Warszawa 2016.

42 Żeby zdefiniować tego typu aparat krytyczny, pojawiają się wciąż nowe określenia, np. „hipermedialny aparat krytyczny" (A. W ój t o w i c z, Narzędzia mediów elektronicznych w warsztacie edytora - próba teoretycznego rozpoznania. „Teksty Drugie” 2014, nr 2, s. 253) albo „digital tools” (M c Gan n, op. cit.).

43 C. Norwid, autograf wiersza W Weronie. Bibl. Jagiellońska, rkps 6100 II.

44 C. Norwid, Nad grobem Julii Capulleti $w$ Weronie. „Pokłosie. Zbieranka literacka na korzyść sierot” 1854 , s. 117.

45 T. Le nartow i c z, autograf listu do J. I. Kraszewskiego, z marca 1860. Bibl. Jagiellońska, rkps 6470 IV, k. 74v. Przedruk w: J. I. Kra s z ew s ki, T. Le na r tow i c z, Korespondencja. Do druku przygotował, komentarzami opatrzył W. D a n e k. Wrocław 1963, s. 66. „Biblioteka Warszawska” 1867, t. 3, s. 225-226. 
gładkiego papieru (verso - inny tekst wiersza Norwida: Co? jej powiedziec), niemal identyczny $z$ wersją drukowana $w$ „Bibliotece Warszawskiej” ${ }^{7}$. W końcu trzeba tu wymienić - podobnie jak ten poprzedni beztytułowy - ołówkowy autograf, który zachował się w dokumentacji rodziny Wagnerów ${ }^{48}$. Trudno ustalić datę jego powstania: być może, to koniec lat sześćdziesiątych lub pierwsza połowa lat siedemdziesiątych XIX wieku. Gomulicki wprawdzie bliżej dookreśla daty (1873-1876), lecz jego hipotezy nie są oparte na silnych przesłankach dokumentacyjnych. Nie sposób sobie wyobrazić, aby każda przed chwilą wymienioną wersję $W$ Weronie odnotowywało i porównywało zwykłe wydanie książkowe, ale w przypadku edycji cyfrowej mamy i warunki, i odpowiednią przestrzeń, i narzędzia, które pozwalają umieścić we właściwych odnośnikach zarazem teksty wszystkich wersji, jak stosowne komentarze, np. pokazujące miejsce tego utworu (czy też poetyckiego fragmentu) w innych strukturach (choćby w strukturach dramatycznych wymienionej tu Nocy tysiacznej drugiej). Nie wspominając już o rozmaitych opcjach zestawień, porównań etc.

Moduł trzeci - który należy (w odpowiednich domenach, tworzonych w formie stosownej rejestracji) do czytelnika - umożliwiałby kreowanie własnych edycji opartych na analizie wykonywanej w module drugim, włącznie $z$ komentarzami i objaśnieniami. Między wszystkimi wskazanymi modułami powinna istnieć ścisła więź operacyjna, co prowadziłoby do utworzenia cyfrowego gabinetu filologicznego, bo w takiej formule, w rzeczy samej, należy rozpoznawać internetowe edycje cyfro$w^{49}$. Oczywiście, te nowe narzędzia i nowa przestrzeń, w jakiej mogłoby funkcjonować Vade-mecum, nie uwalniają wydawcy (także jako gospodarza czynności cyfrowych) od zadawania pytań i rozstrzygania dylematów dotyczących podstawy i editio definitiva, zapewne jednak ułatwiaja prace i powiększaja potencjał analityczny. Edytorstwo bowiem, jak żadna inna dziedzina filologii, w każdej przestrzeni (również i tej internetowej, a może w niej w sposób szczególny) powinno być posłużmy się słowami Norwida - „s umiennością w obliczu źródeł”50.

Go muli cki przypuszcza, że autograf pochodzi z końca 1868 lub początku 1869 r. (PW-2 381). Rękopis tej wersji wiersza znajduje się w Bibl. Narodowej (sygn. IV 6291, k. 43).

Zdaję sobie sprawę, że dotykam kwestii sporu, który - jak przypuszczam - nie zniknie prędko, a mianowicie, czy kategoria wydania hipertekstowego (hypertextual edition) jest rzeczywiście wydaniem ex definitione, czy też stanowi tylko określenie zwyczajowe, faktycznie zaś istotą tego zjawiska jest wyłącznie domena dyspozycji środków, udostępniania źródeł i narzędzi. Pole dyskusji w dużym stopniu wyznaczają niejednokrotnie dzieła i przekazy, jakimi dysponujemy: stan rzeczy. Tak więc np. w przypadku Quidama czy Promethidiona - by trzymać się Norwidowskiego pola - zarysowane przed chwilą miejsce konfliktu będzie właściwie rozbrojone, ale już gdy sięgniemy po Vade-mecum, a zwłaszcza Rzecz o wolności słowa wyda się ono bardzo aktywne i żywe. W przypadku każdego pisarza ta linia demarkacyjna (czy też linie demarkacyjne) przebiega inaczej (zob. M. Tr o s z y ń s k i, Hiperteksty Słowackiego. Z Marią Prussak rozmowa o rękopisach dramatów. W: Słowacki. Poza kanonem. Gdańsk 2014. - M. Piwińska, Refleksje przy lekturze. 〈Marek Troszyński, „Alchemia rękopisu. "Samuel Zborowski“ Juliusza Słowackiego”〉. „Wielogłos” 2019, nr 1).

C. N o rwid, O Juliuszu Słowackim w sześciu publicznych posiedzeniach (z dodatkiem rozbioru „Balladyny”). PW-6 423. 


\author{
Abstract \\ PIOTR CHLEBOWSKI John Paul II Catholic University of Lublin \\ ORCID: 0000-0002-8285-9358
}

\title{
THE PROBLEM OF ESTABLISHING A BASIS FOR CRITICAL EDITION OF CYPRIAN NORWID'S "VADE-MECUM"
}

The article recollects a long-standing so far editorial and research practice of editing Cyprian Norwid's Vade-mecum, and also gives attention to the new textological solutions. To this day, only the manuscript's clean copy or only rough draft was made the editorial basis, and both possibilities referred to the entire collection. The new proposal limits the solutions to each poem, postulating a separate textological analysis (as binding one) to each piece of the cycle. The choice would not pertain to the collection but (due to its incompleteness and roughness) to its individual items. The study also suggests a digital edition of Vade-mecum, an open edition-especially in its material and commentary matterthough also unavoiding editorial completion. 